\title{
Emblemas e pedagogia seráfica: a convergência de dois mundos nas livrarias franciscanas da Província de Santo Antônio do Brasil no Setecentos (Bahia, Pernambuco e Paraíba) ${ }^{1}$
}

Emblems and seraphic pedagogy: two worlds converging in the franciscan libraries at Saint Anthony of Brazil Province (Bahia, Pernambuco and Paraíba $-18^{\text {th }}$ century)

Emblemas y pedagogía seráfica: la convergencia de dos mundos en las librerías franciscanas de la Provincia de San Antonio del Brasil (Bahia, Pernambuco y Paraíba - Siglo XVIII)

Carla Mary S. Oliveira

Universidade Federal da Paraíba (Brasil)

http://lattes.cnpq.br/6118364027975117

http://orcid.org/0000-0002-9642-8081

cmsoliveira.ufpb@gmail.com

\section{Resumo}

Desde o século XV a Emblemática tornou-se um dos muitos temas de interesse da cultura humanista cultivada entre a nobreza e os homens de letras na Europa do Renascimento e, depois, nas centúrias seguintes, do Barroco. Entre os religiosos, especialmente no que diz respeito às ordens conventuais e congregações que primavam pela formação instrucional de seus quadros, como inacianos e franciscanos, percebeu-se as enormes possibilidades do uso da Emblemática não apenas no desenvolvimento intelectual de seus noviços, mas também no trabalho de catequese a ser feito no mundo laico, especialmente no Novo Mundo. A intenção deste trabalho é discutir a presença de algumas obras de Emblemática no acervo das livrarias conventuais da Província Franciscana de Santo Antônio do Brasil listados no Livro dos Inventários dos Conventos do Norte [em 5 de julho de 1852] - elaborado pelo Fr. Antônio da Rainha dos Anjos Machado, documento este existente no Arquivo Provincial Franciscano do Recife - analisando-os sob a perspectiva da Pedagogia Seráfica cristalizada nos Estatutos da Província de S. Antonio do Brasil, publicados em Lisboa em 1709, e nas Atas Capitulares Provinciais (1649-1893), publicadas na Revista do IHGB em 1970.

Palavras Chave: Franciscanos. Instrução. Emblemas. Noviços. Século XVIII. América Portuguesa.

\footnotetext{
${ }^{1}$ Este paper foi apresentado na mesa-redonda "Saberes, poderes e globalização" de que participei como convidada, no Colóquio Internacional "Poder, Globalização e Território nas Sociedades Ibero-Americanas: da Modernidade à Contemporaneidade", evento realizado na Universidade de Évora, em Portugal, entre 23 e 25 de julho de 2018 (http://www.pgt.uevora.pt/programa/). O trabalho apresenta resultados parciais do Projeto de Pesquisa "Os franciscanos e a Pedagogia Seráfica: Instrução e História da Leitura nas Capitanias/ Províncias do Norte do Estado do Brasil (séculos XVIII e XIX)”, financiado por meio do Edital Universal CNPq nº 001/2016 Faixa B [processo nº 402877/2016-0], vigente entre 13 jun. 2017 e 31 mai. 2020.
} 


\begin{abstract}
Since the $15^{\text {th }}$ century the Emblem became one of the many themes of interest of the humanist culture cultivated between the nobility and the men of letters in Renaissance Europe and later, in the following centuries of the Baroque. Among the religious, especially with regard to the conventual and others orders that it were used for the instructional formation of their priests and friars, as among both Ignatians, Franciscans and others, the enormous possibilities of the use of the Emblems were perceived not only in the intellectual development of their novices, but also in the work of catechism to be done in the secular world, especially in the New World. The intention of this paper is to discuss the presence of some works of Emblematic in the collection of the convent libraries of the Franciscan Province of Saint Anthony of Brazil listed in the Book of Inventories of the Convents of the North [July 5, 1852] - elaborated by Friar Antônio da Rainha dos Anjos Machado, an existent document in the Franciscan Provincial Archives of Recife - analyzing this one from the perspective of the Seraphic Pedagogy crystallized in the Statutes of the Province of Saint Anthony of Brazil, published in Lisbon in 1709, and in the Provincial Chapter Acts (1649-1893), published in the Brazilian Historical and Geographical Institute Journal in 1970.
\end{abstract}

Keywords: Franciscans; Learning; Emblems; Novices; $18^{\text {th }}$ Century; Portuguese America.

\title{
Resumen
}

Desde el siglo XV la Emblemática se ha convertido en uno de los muchos temas de interés de la cultura humanista cultivada entre la nobleza y los hombres de letras en la Europa del Renacimiento y después en las centurias del Barroco. Entre los religiosos, especialmente en lo que se refiere a las órdenes conventuales y congregaciones que primaban por la formación instruccional de sus cuadros, como inacianos y franciscanos, se percibió las enormes posibilidades del uso de la Emblemática no sólo en el desarrollo intelectual de sus novicios, trabajo de catequesis a ser hecho en el mundo laico, especialmente en el Nuevo Mundo. La intención de este trabajo es discutir la presencia de algunas obras de Emblemática en el acervo de las librerías conventuales de la Provincia Franciscana de Santo Antônio do Brasil listados en el Libro de los Inventarios de los Conventos del Norte [5 de julio de 1852] - elaborado por el Fr. Antônio da Rainha dos Anjos Machado, un documento existente en el Archivo Provincial Franciscano de Recife - analizándolos desde la perspectiva de la Pedagogía Seráfica registrada en los Estatutos de la Provincia de S. Antonio de Brasil, publicado en Lisboa en 1709, y en las Actas Capitulares Provinciales (1649-1893), publicadas en la Revista del Instituto Histórico y Geográfico Brasileño en 1970.

Palabras Clave: Franciscanos; Educación; Emblemas; Novicios; Siglo XVIII; América portuguesa. 
Melior est enim sapientia cunctis pretiosissimis: et omne desiderabile ei non potest conparari.

Provérbios, $8: 11 .^{2}$

\section{Ao modo de um introito}

Talvez uma das melhores maneiras de se aproximar da compreensão do sentido das coisas em qualquer outra temporalidade seja fazê-lo por meio de como as definiam as palavras naquele pensar distante do qual, tal como perscrutadores com ouvidos atentos, almejamos identificar qualquer sussurro que nos indique que direção seguir, que caminho escolher para encontrar o roteiro de sua decifração mágica. Que dizer então quando se está tentando entender o que se fazia com a junção de imagens e palavras num outro tempo, num mundo que nos parece estrangeiro, onde se percebia tudo a partir de outras chaves de pensamento, a partir de conexões muito diversas daquelas que hoje usamos? O que se entendia, portanto, como um emblema no mundo de fala portuguesa em começos do setecentos?

Pois bem. Antes de adentrar esse mundo dos emblemas e sua relação com os franciscanos radicados na América portuguesa, penso ser necessário primeiro buscar saber o que se dizia sobre tal forma de representação àquela época, de que maneira se lhes atribuía sentido, como se explicava não apenas sua essência, mas também seus usos e objetivos para a cultura de então. O Pe. Raphael Bluteau (1638-1734), da Ordem dos Clérigos Regulares, assim os definia em 1712, em seu Vocabulario Portuguez e Latino, impresso nas oficinas do Colégio dos Jesuítas em Coimbra:

EMBLEMA, Emblèma. He palavra Grega, derivada do verbo Emballo, que significa duas cousas contrarias, a saber, Metter dentro, \& Botar fora, \& o que os Gregos chamavão Emblimata, erão huns ornamentos, ou peças postiças, que se pegavã aos vasos de ouro, ou prata, \& quando se queria, se tiravão. Budaus in anno Pr. \& Caelli. Também por esta palavra Emblemata, entenderão os antigos as folhagens da escultura, as brochas dos arnezes, festoens, relevos, \& outras obras, \& lavores, que forão chamados Argumenta, Parerga, Anaglypta, Chrysendeta, dedalmata, \& ornamenta exemptilia. Hoje, entre Humanistas, Emblema, he termo metaphorico, porque da significaçaõ de ornamentos materiaes, passou a significar algũ documento moral, que aberto em estampas, ou pintado em quadros, se põem para ornamento das falas, galerias, Academias, Arcos triumphaes, \&c. O Emblema tem, como a divisa, ou empresa, corpo, \& alma, a saber, figura visivel, \& letra intelligivel, porem em muytas cousas differe Emblema de Empresa. 1. Tanto mais perfeyta he a Empresa, ou Divisa, quanto mais simplez, \& cõposta de menos figuras. Mas o Emblema admitte varias figuras, historicas ou fabulosas, naturaes, ou artificiosas, verdadeyras, ou chimericas; ně exclue, como a Empresa, corpos humanos; mas antes com erudita moralidade às vezes representa hum Ganimedes, que sobe, hum Dedalo, que voa, hum Phaetonte, que cahe, \&c. 2. O objecto da Empresa (segundo o seu uso primitivo) he Heroico, \& Particular. O

\footnotetext{
${ }^{2}$ Versículo retirado do Antigo Testamento e registrado, em forma reduzida, na decoração rococó da livraria conventual franciscana do Recife, datada do século XVIII. Tradução livre: "A sabedoria é melhor do que todas as coisas mais preciosas: e tudo desejável não pode ser comparado a ela".
} 
objecto do Emblema, he hum documĕto geral, concernente ao instituto da vida humana. 3. A Empresa, como sutil, engenhosa, \& rebuçada, usa de letra ambígua, \& lacônica, que declarando encubra, \& encobrindo declare, o que significa. Pelo contrario o Emblema, como familiar, popular, liso, \& sincero, clara, \& diffusamente expoem, o que ensina. Finalmente podem a empresa, \& o emblema ter o mesmo corpo, ou figura, mas não a mesma alma, ou letra, porque a letra da empresa há de ser propria, \& particular, \& a letra do emblema há de ser geral, \& dogmática; \& com esta advertência mudando a alma, \& não o corpo, quero dizer mudando a letra sem mudar a figura, poderas fazer da empresa, emblema, \& do emblema, empresa. Emblema, atis. Neut. Usa Cicero desta palavra no sentido em que usavão della os antigos Gregos, \& Latinos. Nem sey, como se introduzio, \& permaneceo na lingoa Latina esta palavra, porque diz Suetonio, que Tiberio a mandara riscar, \& rapar de hum degráo do Senado, porque era palavra, mendigada de huma lingoa estrangeyra. ${ }^{3}$

O mais interessante é que já em 1789, ao revisar a obra do Pe. Bluteau para uma nova edição impressa em Lisboa, Antonio de Moraes Silva reduziria muitíssimo o verbete, dandolhe nova redação, extremamente sucinta:

EMBLEMA, s. m. figura, geroglifico, ou simbolo, que allude a alguma moralidade, a qual de ordinario se declara por alguma letra, mote, ou rotulo á figura; empresa, divisa, o emblema contèm moralidade geral; a empresa, ou divisa, particular. ${ }^{4}$

Em quase 80 anos, a importância dada à explicação do termo parece ter decaído bastante nos círculos eruditos de fala lusa, haja vista que o dicionário de Bluteau era das obras mais conceituadas em Portugal e em suas colônias durante todo o setecentos. No entanto, há que se considerar que, se ocorria uma mudança na maneira de se enxergar o estar-no-mundo no espaço profano, deixando-se de dar a mesma relevância a uma linguagem que desde os começos da Idade Moderna se convertera numa chave de compreensão amplamente utilizada nos meios letrados em geral - a começar com a publicação, em 1499, do romance alegórico Hypnerotomachia Poliphili ["Disputa Amorosa Onírica de Poliphilo"], de Francesco Colonna, nas oficinas tipográficas venezianas de Aldus Manutius ${ }^{5}$ e, poucas décadas mais tarde, com a aparição do Emblematum Libellus ["Livrinho de Emblemas"] de Andrea Alciato ${ }^{6}$, impresso em Augsburgo em 1531 - a verdade é que nos meios conventuais e religiosos católicos a ideia central da Emblemática, tal como se apresentava já cristalizada nos séculos XVI e XVII, se prestava extremamente bem à sua utilização na construção de imagens mentais associadas à catequese e à admoestação moral.

Essa qualidade didática dos emblemas logo cedo foi percebida pelos inacianos, que desde as primeiras décadas de sua ação missionária já agregavam seu uso às práticas de instrução formativa e também ao cultivo intelectual de seus religiosos. Esse, aliás, é um aspecto destacado por Luís Gomes no verbete referente ao termo "emblema" do E-Dicionário de Termos

\footnotetext{
${ }^{3}$ VOCABULARIO, 1712, letra E, p. 43-44, grifos do autor.

${ }^{4}$ DICCIONARIO, 1789, p. 470.

${ }^{5}$ COLONNA, 1499.

${ }^{6}$ ALCIATI, 1534.
} 
Literários $^{7}$. Os padres jesuítas sabiam muito bem utilizar os elementos constitutivos dos emblemas para, a partir deles, estruturar suas prédicas, desvelando aos fiéis, a partir de uma imagem aparentemente simples, cada uma das muitas e complexas possíveis camadas de significados nelas contidas, como se seus sermões fossem uma revelação mágica da palavra sagrada, e não uma construção intelectual muito bem orquestrada com a finalidade de conseguir o efeito persuasivo da catequese. O Pe. Louis Richeome, S.J. (1544-1625), autor de Tableaux sacrez des figures mystiques du très auguste sacrifice et sacrement de l'Eucharistie, publicado pela primeira vez em Paris em 1601, afirmava que as imagens ensinavam de maneira "proveitosa, vívida e deleitosa" as coisas de Deus, e ele detalhava tais vantagens claramente, ao enumerar as utilidades dos emblemas na propagação das coisas da Fé e em defesa da Eucaristia:

[...] não há nada mais deleitoso, que não deixe algo mais docemente na alma, do que a pintura, que não a grave mais profundamente na memória; que não mais efetivamente motive a vontade a avançar, e energicamente encoraje-a a amar ou odiar o bom ou mau objeto que lhe foi proposto, isto é, não vejo de que maneira mais proveitosa, vívida e deleitosa se pode ensinar as virtudes, os frutos e as delícias deste divino e sagrado alimento do corpo do Filho de Deus [= a Eucaristia], que com as referidas exposições e com o ar desta tríplice pintura: do desenho, da palavra e do significado. ${ }^{8}$

Vê-se, desse modo, que o uso dos emblemas entre os membros da Companhia de Jesus chegou ao ponto mesmo de várias obras terem sido escritas por padres inacianos com o objetivo explícito de apresentar temas da doutrina por meio da Emblemática. Esse também foi o caso do Lux Evangelica sub Velum Sacrorvm Emblematvm Recondita in Anni Dominicas Selecta Historia \& Morali Doctrina Variè Advmbrata ${ }^{9}$, obra do Pe. Heinrich Engelgrave, S.J. (16101670), editado pela primeira vez em 1648, e que pode ser considerado como um dos melhores sinais desse uso, chegando mesmo ao ponto de figurar profusamente no acervo de livrarias ${ }^{10} \mathrm{de}$ diversas outras ordens, como as dos franciscanos observantes, com o objetivo explícito de servir na instrução de noviços e jovens religiosos recém professos.

\footnotetext{
${ }^{7} \mathrm{O}$ trecho do verbete: “O emblema é, por natureza, didáctico, procurando impressionar o leitor com a figura e persuadi-lo com o texto, embora seja indicado também como fonte iconográfica de motivos para artes plásticas. Originalmente com uma intenção lúdica, os emblemas vêm a servir uma grande variedade de audiências (com uma igual variedade de temas e motivos, do amor profano ao religioso, da moral à justiça e à guerra) e a desempenhar outras funções, como propagandística (explorada pela ordem jesuíta nos séculos XVII e XVIII) e científica (os livros de emblemas de Joachim Camerarius)" (GOMES, 2009).

${ }^{8}$ RICHEOME, 1601, p. 7. O texto original, em francês do início do século XVII: “[...] il n y’a rien qui plus délecte, ne qui face plus suavement glisser une chose dãs l'âme, que la paincture: ne qui plus profondemĕt la grave en la memoire; ne qui plus efficacement pousse la volonté pour luy donner branle, \& l'esmouvoir avec énergie à aymer ou hayt l'obiect bon ou mauvais qui luy aura esté proposé, ie ne vois pas en quelle manière on puisse plus profitablement, vivement, \& délicieusement enseigner les vertus, les fruicts \& les délices de ce divin \& sacré mets du corps du Fils de Dieu, qu'avec les susdites expositions \& avec l'air de ceste paincture triple, de pinceau, de parole \& de signification".

${ }^{9}$ ENGELGRAVE, 1648, 1654, 1655a, 1655b. Tradução livre, aproximada, do título: "Luz do Evangelho oculta sob o véu dos Sacros Emblemas, distribuída pelos Domingos do Ano com a História e Doutrina Moral e vários Testemunhos".

${ }^{10}$ Termo que até a primeira metade do século XIX era usado como sinônimo de biblioteca no mundo de língua portuguesa, e definia o espaço dedicado à guarda dos livros e sua consulta pelos leitores, inicialmente junto às Sés e catedrais, e depois em conventos, mosteiros, seminários, colégios e universidades. Também era utilizado para nomear as coleções particulares. A expressão aparece definida como "Lugar onde estão muitos livros em estantes" e "Bibliotheca" no dicionário do Pe. Raphael Bluteau (VOCABULARIO, 1716, vol. 5, p. 163).
} 
Somente na livraria do Convento de Santo Antônio da Paraíba, por exemplo, consta no inventário feito em julho de $1852^{11}$ - quando da decadência irremediável da Província de Santo Antônio do Brasil - que existiam cinco exemplares de Emblemática, divididos entre dois exemplares do Lux Evangelica do Pe. Engelgrave e mais três do Mundus Symbolicus in Emblematum Universitate Formatus, explicatus, et tam Sacris, quàm profanis Eruditionibus ac Sententiis illustratus ${ }^{12}$, do Pe. Filippo Piccinelli (1604-c.1679), cônego agostiniano, do qual a primeira edição, em italiano, fora publicada em 1635. Apenas esta pequena mostra já assinala o quão pode render a abordagem do tema no mundo da instrução das casas seráficas no Brasil colonial, seara que ainda não recebeu a devida atenção nas pesquisas de História dos Livros e da Leitura e de História da Educação até o momento.

Mas o que interessa considerar ao começar aqui a abordar esse tema e, mais ainda tendo como cenário a América portuguesa, é que se no setecentos a República das Letras já caminhava a passos largos para a consolidação dos ideais das Luzes na Europa, do outro lado do Atlântico o aparente hermetismo alegórico dos emblemas se prestava muito bem às construções mentais próprias do Barroco, calcadas em uma densa simbologia engendrada a partir de tradições orais cotidianas, profundamente amalgamadas pelo ritmo das coisas do sagrado, constituindo assim um vasto vocabulário franqueado à ação catequética das ordens religiosas ali instaladas de braços dados ao domínio da Coroa lusa. Nesse sentido, cabe detalhar do que se está falando de fato. Quais são, portanto, os elementos constitutivos de um emblema? Ehrenfried Kluckert sintetizou muito bem, em verbete de obra panorâmica sobre o universo barroco, as partes essenciais dessa forma de representação tão difundida entre os séculos XV e XVIII no mundo ocidental:

Um emblema é composto pela pictura ou figura, a inscriptio ou moto, e a subscriptio, epigrama em latim. A figura, também designada como imago ou symbolon, representa todos os motivos imagináveis, tanto da vida quotidiana como do reino animal ou vegetal. $\mathrm{O}$ moto, que surge no topo da figura, remete para o tema do emblema representado na imagem. Por fim, a subscriptio esclarece e interpreta aquilo que se encontra representado no emblema. É frequente encontrar nos emblemas expressões que reflectem sabedoria de vida ou conselhos morais. ${ }^{13}$

Ao agregar a Emblemática aos usos próprios da prática religiosa cristã, especialmente no contexto da Reforma Católica e no que diz respeito à fixação de preceitos morais e temas pios ligados aos dogmas da Fé ou mesmo às histórias e relatos do Antigo Testamento ou dos Evangelhos, ou ainda a questões filosóficas e teológicas, adaptando sua apresentação ao discurso imagético, poético e simbólico típico dessa forma de expressão da transição do Renascimento ao Barroco, obviamente foram feitas adaptações por parte dos autores das obras com esse tipo de enfoque. Talvez a mais marcante seja a introdução de um texto em prosa mais longo explicando a pictura, muitas vezes fornecendo os elementos a serem utilizados num sermão ou prédica religiosa. Obviamente, muitos dos livros de Emblemática com essa abordagem eram escritos por religiosos, por isso mesmo não deve causar espécie que tais obras circulassem nas livrarias das casas conventuais e seminários de muitas ordens, mesmo que seu autor pertencesse a uma congregação diversa, algumas até com disputas entre si - como foi o caso dos franciscanos observantes portugueses que instalaram a Custódia/ Província de Santo Antônio do Brasil e os

\footnotetext{
${ }^{11}$ Arquivo Provincial Franciscano do Recife - APFR. Livro dos Inventarios dos Conventos do Norte [em 5 de julho de 1852], feito por Fr. Antônio da Rainha dos Anjos Machado, 104 fólios.

12 PICCINELLI, 1687. Tradução livre, aproximada, do título: "Mundo Simbólico em Emblemas Universais formado, explicado, tanto em Sacras quanto em Profanas e Muito Eruditas Sentenças Ilustrado".

${ }^{13}$ KLUCKERT, 2004, p. 428.
} 
jesuítas, envolvidos em querelas acerca dos aldeamentos indígenas na Paraíba e que resultaram na expulsão dos inacianos da Capitania em 1593.

Na figura a seguir é possível visualizar esta adaptação numa das muitas edições do Theatro Moral de la Vida Humana, de Otto Van Veen (1556-1629), publicado originalmente em $1607^{14}$ com um título diferente, em que se destacava a ligação com a inspiração principal de seus emblemas, a poesia clássica de Horácio. De grande circulação por toda a Europa entre os séculos XVII e XVIII, tal obra, apesar de não ser de autoria de um religioso, teve aceitação enorme nos meios católicos europeus, pois Van Veen - que eventualmente assinava com a forma latinizada Vaenius - durante certo período serviu a D. Isabel Clara Eugenia, filha de Filipe II e governadora das possessões espanholas nos Países Baixos no início do século XVII, ou seja, o artista - que também foi responsável por parte da formação de Peter Paul Rubens e o teve como seu aprendiz - estava acostado ao círculo mais íntimo dos ideais contrarreformistas pós-tridentinos ${ }^{15}$.

Fig. 1 - "Virtus Inconcussa" ou "La Virtud es Immovible", primeiro emblema do Theatro Moral de La Vida Humana, de Otto Van Veen, junto com sua explicação na página anterior, numa edição publicada em Antuérpia, no ano de 1733 [p. 2-3], na tipografia da Viúva de Heinrich Verdussen. Em destaque os elementos tradicionais de um emblema, respeitados por Van Veen, aos quais ele acrescentou antes dos versos de Horácio em Latim a explicação do emblema em prosa, onde também se apresentam o livro e os objetivos da obra, depois seguidos de versos em castelhano.

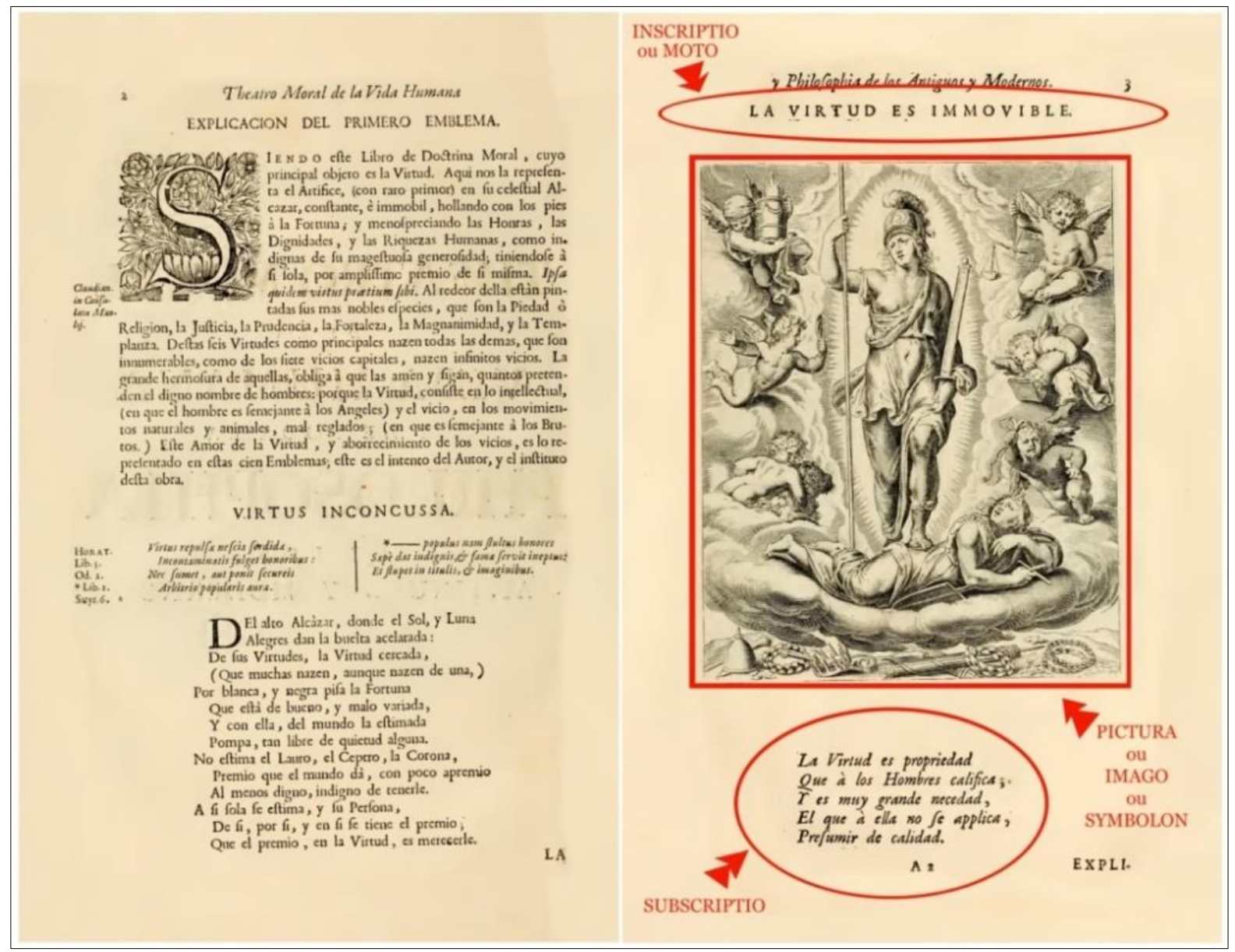

Fonte: http://www.archive.org/.

\footnotetext{
${ }^{14}$ CORNELLES, 2013, p. 25.

${ }^{15}$ CORNELLES, 2013, p. 27.
} 


\section{As obras de Emblemática nos acervos das livrarias franciscanas da América Portuguesa: a circulação de saberes no mundo atlântico barroco ${ }^{16}$}

Ao contrário de suas similares europeias, que preservaram seus livros mais antigos graças tanto ao clima como a uma cultura de letramento e uma estrutura instrucional conventual mais sólida e completa, na América portuguesa os ares tropicais não beneficiaram as livrarias franciscanas do período colonial, pois facilitaram a proliferação de micro-organismos, insetos e fungos que danificaram irremediavelmente quase tudo que havia de livros preciosos nesses espaços ainda na segunda metade do século XIX, quando da extinção da Província à míngua, devido à proibição, por parte do Império brasileiro, do ingresso de noviços em todas as ordens religiosas ${ }^{17}$.

No entanto, muito embora não seja mais possível consultar diretamente os acervos dessas livrarias tal como eles se apresentavam no setecentos em seus locais originais, folheando as páginas de suas obras impressas in folio $^{18}$, in quarto ${ }^{19}$ ou in octavo ${ }^{20}$, ao menos em relação a três desses ambientes de leitura, instrução e erudição ainda se pode ter uma noção muito próxima dos volumes que povoavam suas estantes de feição barroca, graças ao Livro dos Inventarios dos Conventos do Norte ${ }^{21}$, documento elaborado em meados de 1852 pelo Fr. Antônio da Rainha dos Anjos Machado, com vistas à possível transferência de parte desse acervo para a biblioteca da Faculdade de Direito do Recife ${ }^{22}$.

Além disso, por meio de levantamento feito pelo Fr. Hugo Fragoso na década de $1990^{23}$ sabe-se também que alguns volumes da livraria conventual de Salvador ainda se conservam em dois armários da atual biblioteca daquele cenóbio, mas nenhum restou dos acervos de Igarassu ou da Paraíba. Possivelmente um ou outro volume listado como pertencente ao convento olindense no Livro dos Inventarios pode estar ou no acervo da Biblioteca Pública do Estado de Pernambuco ou então na Biblioteca da Faculdade de Direito do Recife, vinculada à Universidade Federal de Pernambuco. Da livraria do convento do Recife, nada restou, como relatado por Pereira da Costa ainda no final do oitocentos ${ }^{24}$. A livraria do convento de Ipojuca, infelizmente, arruinou-se no incêndio de 1939 que destruiu parte daquela casa religiosa ${ }^{25}$.

\footnotetext{
${ }^{16}$ Os dados tabulados aqui apresentados quanto à temática dos acervos das livrarias franciscanas estudadas foram organizados por Lucas Gomes Nóbrega, graduado em História pela UFPB e mestrando no PPGH-UFPB, quando foi meu bolsista de Iniciação Científica PIBIC/UFPB/CNPq desenvolvendo o plano de trabalho "As livrarias franciscanas entre o setecentos e o oitocentos: acervos e temáticas em Pernambuco e na Paraíba", entre agosto de 2016 e julho de 2017 e cujo Relatório Final foi premiado na área de Ciências Humanas durante o XXV Encontro de Iniciação Científica da UFPB, em outubro de 2017. OBS.: diversos títulos tabulados aparecem com mais de um volume nos acervos de cada uma das livrarias conventuais.

${ }^{17}$ Tal medida se deveu à não resolução de uma divergência entre o Império brasileiro e a Santa Sé em questões relativas ao Padroado (MIRANDA, 1969, p. 92).

18 Após a invenção e disseminação do uso da prensa de tipos móveis por Gutenberg na primeira metade do século XV, na Europa do início da Idade Moderna, se começou a usar esta expressão para definir o tamanho daqueles livros em que se utilizava uma folha de papel para imprimir duas páginas em cada um de suas faces, dobrando-a ao meio, o que resultava na impressão de 4 páginas. Não havia padronização, mas cada página do formato in folio podia corresponder até o tamanho de uma folha A3, ou seja, um volume em que as páginas era de grandes dimensões, com cerca de até 29 X $42 \mathrm{~cm}$.

${ }^{19}$ Nos livros de formato in quarto, as folhas de papel, após impressas, eram dobradas duas vezes, resultando em quatro folhas, ou oito páginas, cujo tamanho se aproximava do atual A4, ou seja, cerca de 21 X $29 \mathrm{~cm}$.

${ }^{20}$ Nos livros de formato in octavo, as folhas de papel, depois de impressas, eram dobradas três vezes, resultando em oito folhas, ou dezesseis páginas, cujo tamanho se aproximava do atual A5, ou seja, cerca de 15 X $21 \mathrm{~cm}$.

${ }^{21}$ LIVRO dos Inventarios dos Conventos do Norte [em 5 de julho de 1852], Fr. Antônio da Rainha dos Anjos Machado (OFM), manuscrito, 104 fólios. Arquivo Provincial Franciscano do Recife - APFR.

22 ALMEIDA, 2012, vol. 1, p. 199.

${ }^{23}$ FRAGOSO, s.d., apud ALMEIDA, 2012, vol. 2, p. 482-491.

${ }^{24}$ COSTA, 1965, p. 227-228.

${ }^{25}$ Para mais detalhes sobre os destinos dos acervos bibliográficos das livrarias dos conventos de Recife e Ipojuca, ver: OLIVEIRA, 2016.
} 
Fig. 2 - Folha de rosto do Livro dos Inventarios dos Conventos do Norte, manuscrito datado de 5 de julho de 1852, elaborado pelo Fr. Antônio da Rainha dos Anjos Machado, OFM.

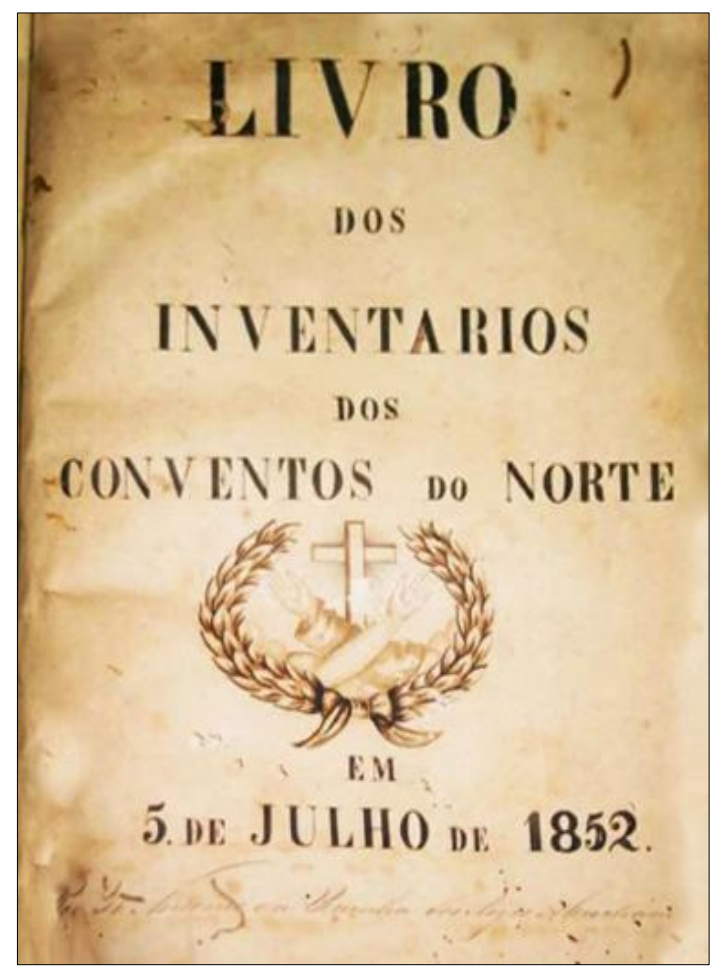

Fonte: Acervo do Arquivo Provincial Franciscano do Recife. Foto da autora, 2015.

A situação que se apresenta como viável à pesquisa, portanto, é se partir para a busca dos vestígios que restaram na documentação e levantamentos existentes, para tentar, mesmo que minimamente, pensar aquele universo de leitura, leitores e circulação de saberes e visões de mundo que engendrava e era engendrado pelas relações simbólicas que permeavam a cultura típica do Barroco, cristalizada de maneira muito peculiar nas obras de Emblemática.

Desse modo, a partir do levantamento de Fr. Fragoso já em finais do século XX sobre o acervo da livraria do convento de São Francisco da Bahia, em Salvador, e da listagem preparada pelo Fr. Machado em 1852, mesmo que se considere que esta última pode conter incongruências e equívocos, dada a quantidade de itens registrados, é possível estabelecer uma visão panorâmica sobre os acervos das livrarias dos conventos de Nossa Senhora das Neves de Olinda, Santo Antônio de Igarassu e Santo Antônio da Paraíba. Contudo, se a notação dos dados sobre as obras em ambos os documentos não é uniforme, os registros quanto à autoria ou título completo de cada livro por muitas vezes estão ausentes, bem como sua data e, obviamente, o local de sua publicação ${ }^{26}$, o que poderia dificultar qualquer inferência sobre o acervo, mesmo assim, e graças ao acurado trabalho de pesquisa feito pelo Fr. Marcos Antônio de Almeida, OFM - em sua tese de doutorado defendida junto à École des Hautes Études en Sciences Sociales, sob orientação de Serge Gruzinski - que conseguiu completar muitas dessas lacunas, me foi possível tabular os principais temas das obras existentes no acervo dessas livrarias num

\footnotetext{
${ }^{26}$ Por meio de um acurado trabalho de pesquisa e cotejamento em sua tese de doutorado, o Fr. Marcos Antônio de Almeida (OFM) conseguiu completar muitas lacunas do Livro dos Inventarios, inclusive a informação de que algumas das obras listadas apenas pela autoria se tratavam de títulos de Emblemática. Por isso, mesmo tendo consultado o documento no Arquivo Provincial Franciscano do Recife, foi imprescindível também o acesso à sua tese para a construção do presente paper. Para maiores detalhes, ver: ALMEIDA, 2012, vol. 2, p. 482-533.
} 
momento em que a Província já estava em decadência já há quase um século ${ }^{27}$, considerando que o total de seus volumes não diferisse muito daquele existente no setecentos, especialmente no que dizia respeito às obras de Emblemática, pois sua publicação e consequente circulação caiu em crescente desuso a partir do último quartel do setecentos.

É esse o panorama que se pode observar nas tabelas a seguir. Antes de abordar especificamente as obras de Emblemática, gostaria de deixar claro que irei situá-las quantitativamente no acervo de cada uma das livrarias conventuais.

\section{A livraria do Convento de São Francisco da Bahia na cidade do Salvador}

A começar a presente análise pela livraria do cenóbio de Salvador, casa fundada em $1587^{28}$, é preciso destacar que sabe-se que ao menos desde 1627 nela funcionava regularmente uma escola custodial, depois provincial ${ }^{29}$, destinada aos estudos maiores dos frades recém-professos, e onde estes deviam receber sua formação nos Studia Artium (Lógica), nos Studia Philosophiae (Filosofia) e nos Studia Theologiae (Teologia).

Especificamente no caso do convento baiano a tabela aqui apresentada é decorrente do trabalho pioneiro do Fr. Hugo Fragoso (1926-2016) na década de 1990, feito a partir de documentação e obras ainda existentes então naquela casa, e que foram complementados pelo Fr. Marcos Antônio de Almeida nas pesquisas que desenvolveu em seu doutoramento junto à EHESS em Paris, sobre a obra do Fr. Antônio de Santa Maria Jaboatão e os franciscanos em Pernambuco no século XVIII ${ }^{30}$.

Num universo de quase 700 volumes levantado por Fr. Fragoso figura apenas um título de Emblemática, com cópias de duas edições diferentes, uma de 1625 e outra de 1648, mas sua presença se espraia também no convento, pois diversas de suas pictura foram utilizadas como modelo na encomenda dos painéis de azulejos setecentistas que decoram as paredes inferiores de seu claustro, espaço dedicado à meditação e oração nas horas livres dos religiosos. Trata-se nada menos do que o Theatro Moral de la Vida Humana, de Otto Van Veen. Dos 103 emblemas de suas páginas, os seráficos escolheram nada menos do que 37 pictura para transformar em encomenda ao ateliê dos mestres azulejeiros lisboetas Bartolomeu Antunes de Jesus e Nicolau de Freitas $^{31}$. Teriam custado, segundo o Fr. Sebastião de Jesus Sant'Ana, guardião do convento entre 1802 e 1804, a vultosa quantia de 2:200\$000

Contudo, a formação do acervo da livraria da casa de Salvador se deu ao longo de todo o setecentos e aparece ao menos em seis momentos anotada no Livro dos Guardiães do convento durante o período, o que denota a importância atribuída àquele espaço e aos livros pelos frades que exerciam a guardiania e também a necessidade de destacar, nos registros oficiais do convento, as grandes compras que aumentaram significativamente o número de exemplares disponíveis aos religiosos em formação e lentes. Em meio ao registro de compra de alfaias, obras de reparo em telhados e ampliação de senzalas, como é comum aparecer no Livro dos Guardiães, é interessante

\footnotetext{
${ }^{27}$ O Decreto Régio de 30 de janeiro de 1764, no rastro da influência do conjunto de reformas promovidas pelo ministro Marquês de Pombal em Portugal, vedou a Província de Santo Antônio do Brasil de receber noviços por catorze anos, o que motivou o início da decadência e retração do número de religiosos seráficos na América portuguesa de forma paulatina, até o oitocentos (MIRANDA, 1969, p. 92).

${ }^{28}$ WILLEKE, 1978, p. 3.

29 A outra escola destinada aos estudos maiores dos frades funcionava no convento de Olinda. Os estudos menores, destinados aos noviços, eram desenvolvidos nos conventos de Paraguaçu, na Bahia, e de Igarassu, em Pernambuco. A este respeito, ver: ATAS, 1970; JABOATAM, 1858, vol. 1, p. 340-343.

30 ALMEIDA, 2012.

${ }^{31}$ MECO, 1998/1999, p. 12.

32 BAZIN, 1983, vol. 2, p. 38.
} 
notar inclusive o detalhamento de alguns autores e a discriminação das dimensões das obras registrando se eram impressos in folio, in quarto ou in octavo.

Em 1743/1746 se anotava, por exemplo, que "[se] meteu, na Livraria, um jogo de Abulensis de 18 tomos" 33 , enquanto que no triênio seguinte o guardião fez comprar " 122 volumes de livros de filosofia, teologia, expositivos, predicativos e históricos" 34 . Duas décadas depois, na guardiania de 1764/1768, "Meteu-se na Livraria a obra de Santo Anselmo, e consertaram-se vários livros que estavam danificados" 35 . Outra grande aquisição foi feita em 1782/1783, quando "Meteram-se na Livraria 65 tomos de livros novos de vários autores, a saber: de fólio, 39; de quarto, 16; de oitavo, 10. Meteram-se mais, com algum uso, os seguintes: de fólio, 20; de quarto, $15^{\prime \prime 36}$. Poucos anos depois, em 1787/1790, "Mandaram-se vir de Lisboa 50 tomos de livros"37. Por fim, a última notação que aparece sobre o acervo de Salvador, já em 1790/1793, registra: "Na Livraria, [compraram-se] vários tomos, já usados. Meteram-se mais quatro tomos de fólio de Houdry" ${ }^{38}$. Considere-se também que, via de regra, os Estatutos provinciais vigentes desde 1708, em capítulo específico, determinavam, "para que as livrarias se provejam de livros com suavidade" que os guardiões de todos os conventos providenciassem, a cada ano e meio, ao menos seis tomos para as livrarias de suas casas, de acordo com as necessidades dos mestres de gramática e lentes de filosofia e teologia ${ }^{39}$.

Como se pode constatar por meio da Tabela 1, as obras de Emblemática representam apenas 0,2\% do total de exemplares oriundos do seiscentos e do setecentos remanescentes na livraria de Salvador e compilados por Fr. Fragoso já em fins do novecentos. Quase $4 / 5$ dos volumes disponíveis aos frades e noviços eram constituídos por obras de Teologia (60\%) e de conteúdos relativos à formação catequética, como os sermões $(19,6 \%)$, o que não deve causar surpresa, já que a casa soteropolitana abrigava um dos dois centros responsáveis pelos estudos maiores do noviciado na Província franciscana.

TABELA 1 - Temas na Livraria Franciscana de Salvador - BA. Levantamento de Fr. Hugo Fragoso - Década de 1990 (obras dos séculos XVII E XVIII - 692 volumes)

\begin{tabular}{ccccc}
\hline TEMAS & $\begin{array}{c}\text { NÚMERO } \\
\text { DE } \\
\text { TÍTULOS }\end{array}$ & $\begin{array}{c}\text { \% SOBRE } \\
\text { TÍTULOS }\end{array}$ & $\begin{array}{c}\text { TOTAL DE } \\
\text { VOLUMES }\end{array}$ & $\begin{array}{c}\text { \% DO } \\
\text { ACERVO }\end{array}$ \\
\hline Emblemática & 1 & 1,8 & 2 & 0,2 \\
Teologia & 29 & 52,7 & 421 & 60 \\
Sermões & 3 & 5,4 & 136 & 19,6 \\
\hline História Eclesiástica & 3 & 5,4 & 39 & 5,6 \\
História Franciscana & 1 & 1,8 & 35 & 5 \\
Direito Canônico & 5 & 9 & 29 & 3,6 \\
Documentos Eclesiásticos \& & 2 & 3,6 & 13 & 1,9 \\
Pontifícios & 2 & 3,6 & 5 & 0,7 \\
Doutrina Católica & 2 & 3,6 & 4 & 0,6 \\
Bíblias & 2 & 3,6 & 7 & 1 \\
Crônica Religiosa & 2 & 3,6 & 2 & 0,3 \\
Filosofia & 1 & 1,8 & 1 & 0,1 \\
Liturgia & 1 & 1,8 & 1 & 0,1 \\
Piedade & 1 & 1,8 & 1 & 0,1 \\
\hline Doutrina Moral & $\mathbf{5 5}$ & $\mathbf{1 0 0 \%}$ & $\mathbf{6 9 2}$ & $\mathbf{1 0 0 \%}$ \\
\hline TOTAL & $2,42-191$ & & \\
\hline \hline
\end{tabular}

Fonte: FRAGOSO, 2006; ALMEIDA, 2012, vol. 2, p. 482-491.

\footnotetext{
${ }^{33}$ WILLEKE, 1978, p. 20.

34 WILLEKE, 1978, p. 20.

${ }^{35}$ WILLEKE, 1978, p. 23.

36 WILLEKE, 1978, p. 27.

37 WILLEKE, 1978, p. 28.

38 WILLEKE, 1978, p. 29.

${ }^{39}$ ESTATUTOS, 1709, p. 137.
} 
No entanto, essa aparente discrepância numérica quanto à disponibilidade das obras de Emblemática naquele acervo não deve ser considerada como um demérito. $\mathrm{O}$ fato de os emblemas das páginas do Theatro Moral de la Vida Humana terem sido trasladados do ambiente da livraria para as paredes do claustro inferior mostra, de forma muito cristalina, a importância dada pelos seráficos à linguagem alegórica da Emblemática como meio de exercitar a meditação religiosa nas coisas do espírito, da moral e dos dogmas cristãos. Todos os elementos decorativos dos conventos seráficos eram pensados nesse sentido, sempre: o de dirigir o pensamento para as coisas da Fé, dentro da cultura histórica do franciscanismo e de suas interpretações acerca do estar-no-mundo. $\mathrm{O}$ fato de que os azulejos com os emblemas estejam numa área de circulação exclusiva dos religiosos, aliás, também só reforça seu papel didático nas atividades da escola provincial.

Fig. 3 - Folha de rosto do Theatro Moral de la Vida Humana, de Otto Van Veen, em edição in folio publicada em Antuérpia, em 1733.

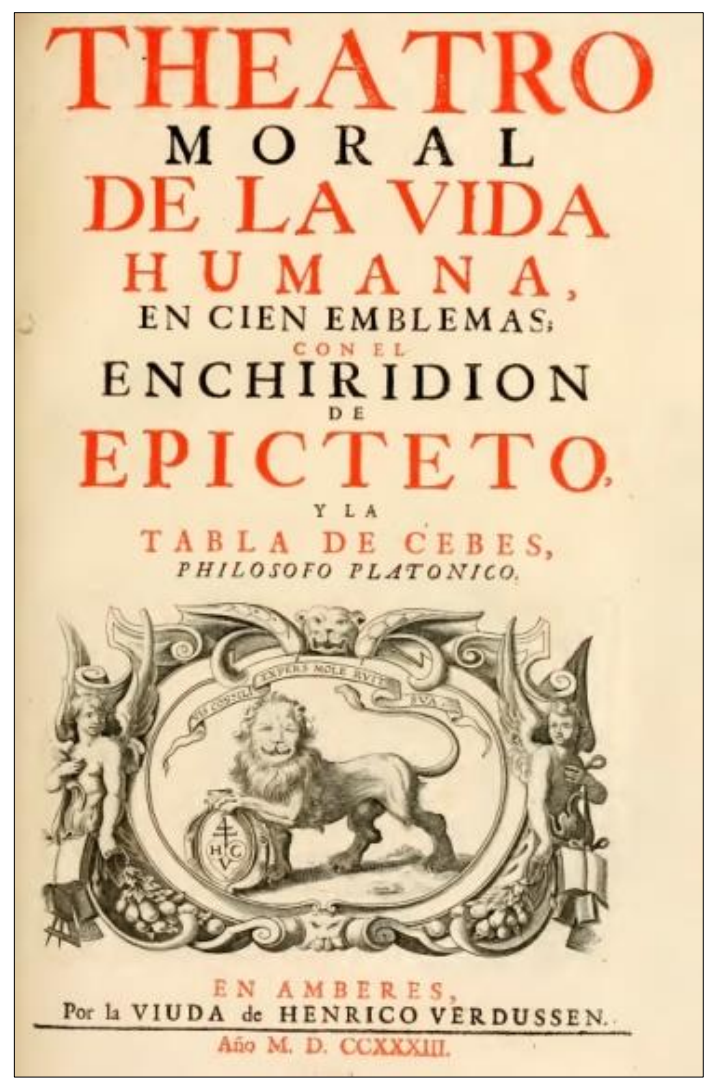

Fonte: http://www.archive.org/.

Fr. Hugo Fragoso também era historiador da ordem franciscana no Brasil e profundo estudioso daquele conjunto de azulejos, e sintetizou muito bem o sentido de seu uso no espaço conventual soteropolitano:

Se toda a vida humana era um teatro, também a vida conventual era expressão de um teatro específico. Em torno dos corredores do claustro desenrolava-se grande parte desse teatro. E aqui teria 
ocorrido algo semelhante a uma osmose entre o teatro real da vida dos frades e a representação teatral nos painéis de azulejos. É que os frades que encomendaram esses azulejos a Lisboa, com toda possibilidade, faziam uma leitura franciscana da filosofia estóica desses painéis. E chama a atenção o fato de que, no final de cada uma das quatro alas há, por sobre o silhar de azulejos, a imagem de um santo. Sua colocação nesse lugar parece ter sido também uma busca de cristianização de todo esse mundo mitológico. ${ }^{40}$

Tomando a proporção da presença de obras de Emblemática no acervo da livraria do convento de Salvador como parâmetro, não deve, portanto, causar espécie que tal patamar seja superado entre as obras das outras três livrarias de que se tem registro documental no oitocentos. Em todas elas são poucos os volumes disponíveis, embora na Paraíba e em Igarassu, se tomadas proporcionalmente em relação ao total de obras, certamente os volumes de Emblemática alcançam maior proeminência frente ao total de obras de ambas as livrarias em meados do XIX.

Fig. 4 - Azulejos do claustro do Convento de São Francisco da Bahia, atribuídos à oficina dos mestres lisboetas Bartolomeu Antunes de Jesus e Nicolau de Freitas, atuantes na década de 1740, baseados nos emblemas do Theatro Moral de la Vida Humana, de Otto Van Veen. Foram assentados entre 1746 e 1748.

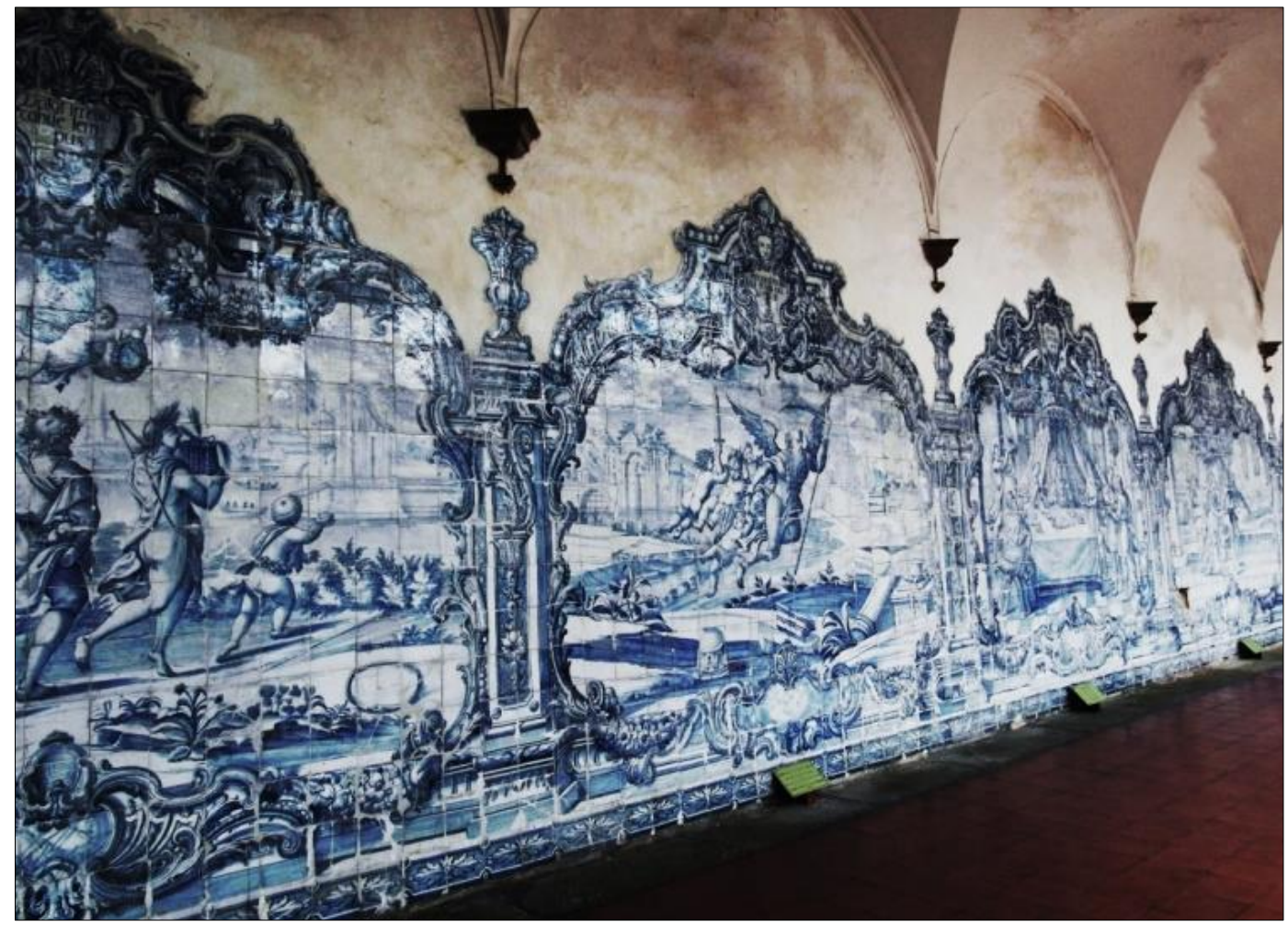

Fonte: Foto da autora, 2007.

${ }^{40}$ FRAGOSO, 2009, p. 338-339. 
Fig. 5 - "Virtus Inconcussa" ou "La Virtud es Immovible", primeiro emblema do Theatro Moral de La Vida Humana, de Otto Van Veen, em pictura de sua edição de 1733, publicada in folio em Antuérpia.

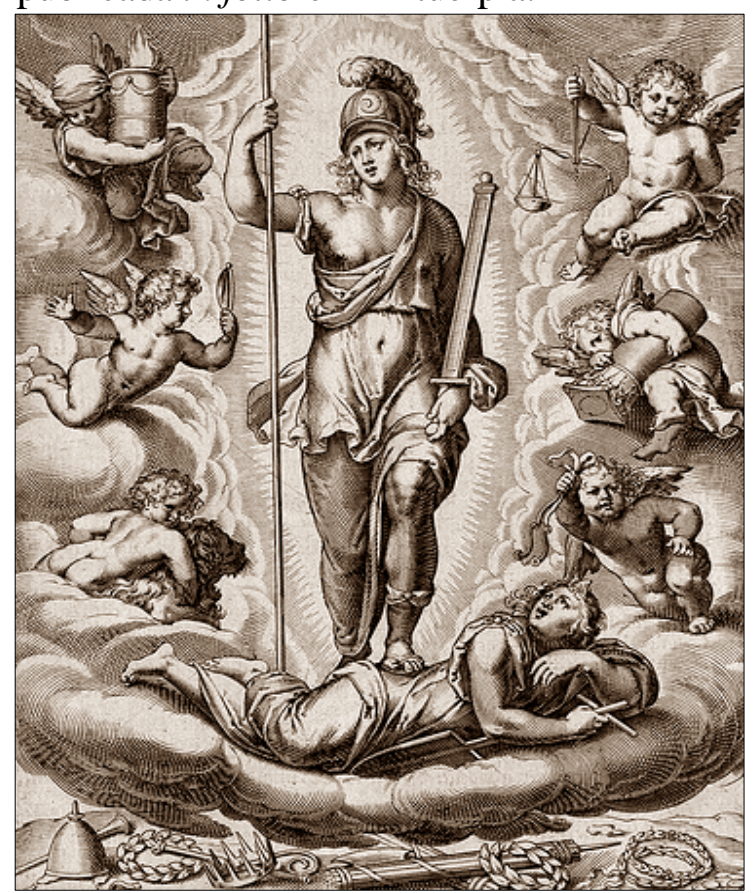

Fonte: http://www.archive.org/.
Fig. 6 - "Virtus in concussa", Bartolomeu Antunes de Jesus e Nicolau de Freitas (atrib.), c. 1740-1745. Ala da igreja, claustro inferior do Convento de São Francisco, Salvador, Bahia.

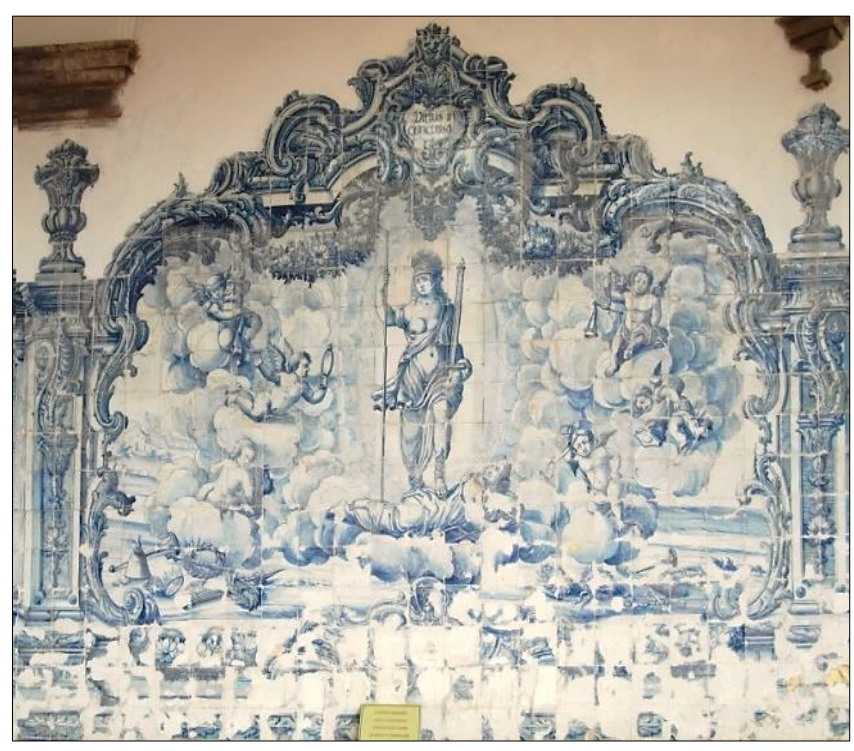

Fonte: Foto da autora, 2007.

Talvez seja, portanto, interessante considerar também de que obras se está falando, no que se refere a essas outras casas seráficas, e qual sua importância e escopo no universo cultural do setecentos, tanto no que se refere à Emblemática mas, especialmente, no campo dos ideais pós-tridentinos e sua relação com a Pedagogia Seráfica.

\section{A livraria do Convento de Nossa Senhora das Neves da Vila de Olinda}

O convento de Nossa Senhora das Neves, em Olinda, por exemplo, era a outra casa na Província franciscana que também abrigava parte dos jovens frades depois que estes realizavam seus primeiros votos, e era lá que eles deveriam realizar seus estudos maiores, e durante mais dois anos aprofundar sua formação no campo das três áreas já iniciadas nos estudos menores, distribuídas em diversas disciplinas como Retórica, Grego e Hebraico - estas três obrigatórias na formação inicial do noviciado - além de Filosofia, História Eclesiástica, Teologia Dogmática, Teologia Moral e Teologia Exegética ${ }^{41}$.

Nossa Senhora das Neves foi o primeiro convento fundado pelos seráficos no Brasil, em $1585^{42}$, quando de fato se instalou a Custódia, ainda subordinada aos observantes portugueses, e já em 1607, quando da realização do Capítulo provincial em Lisboa, se deliberou pela criação de Curso de Artes e Teologia no cenóbio, "por haver mais comodo para isso, nem poderem os argumentos \& exercicios do estudo distrair mas antes edificar aos noviços que nella há"43.

\footnotetext{
${ }^{41}$ AMORIM, 1999, p. 375.

42 BAZIN, 1983, vol. 2, p. 128.

${ }^{43}$ ACTAS, 1607 apud AMORIM, 1999, p. 369.
} 
Desse modo, há que se considerar realmente que a livraria conventual de Olinda tivesse um acervo de dimensões consideráveis no setecentos. Seguindo-se a listagem do Livro dos Inventarios do Fr. Antônio da Rainha dos Anjos Machado, inclusive para a rubrica "Assuntos Diversos" - muito evasiva em maiores detalhes sobre as obras aliás - chega-se a uma incongruência, pois o documento de 1852 informa um total de 896 volumes, acrescida de 30 tomos de Teologia Dogmática que estariam fora do convento, em empréstimo, na residência de um certo Dr. Farias ${ }^{44}$, no entanto contabilizando-se o total de volumes informado para cada título chega-se a um total de mais de 1.200 livros. Considerando que o Relatório de Francisco Augusto Pereira da Costa preparado para o Governo da Província de Pernambuco em junho de 1886 apontava a existência de 1.578 volumes na livraria do convento franciscano do Recife, então completamente imprestáveis para serem relocados à Biblioteca Pública Provincial, motivo da elaboração do documento, acredito que o acervo da livraria de Olinda girasse realmente em torno dos 1.200 volumes em $1852^{45}$.

Como se pode perceber na Tabela 2, que traz a discriminação dos temas dos volumes da livraria olindense, as obras de Emblemática em seu acervo representavam apenas $0,7 \%$ do total de livros, com somente três títulos:

TABELA 2: Temas na Livraria Franciscana de Olinda/PE (inventário de 1852-96 [1.248?] volumes $)^{46}$

\begin{tabular}{|c|c|c|c|}
\hline TEMAS & $\begin{array}{c}\text { NÚMERO } \\
\text { DE } \\
\text { TÍTULOS }\end{array}$ & $\begin{array}{l}\text { TOTAL DE } \\
\text { VOLUMES }\end{array}$ & \% DO ACERVO \\
\hline Emblemática & 3 & 9 & 0,7 \\
\hline Teologia \& Estudos Bíblicos & 62 & 362 & 29 \\
\hline Sermões & + de $100[?]$ & 297 & 23,8 \\
\hline História Eclesiástica & 7 & 113 & 9 \\
\hline Moral & 15 & 26 & 2,1 \\
\hline Bíblia & 2 & 25 & 2 \\
\hline História Franciscana & 5 & 22 & 1,8 \\
\hline $\begin{array}{c}\text { Documentos Eclesiásticos \& } \\
\text { Pontifícios }\end{array}$ & 10 & 20 & 1,6 \\
\hline Filosofia & 8 & 17 & 1,4 \\
\hline Direito Canônico & 3 & 10 & 0,8 \\
\hline Dicionário & 4 & 14 & 1,1 \\
\hline Mística & 5 & 7 & 0,6 \\
\hline Estudos Marianos & 4 & 7 & 0,6 \\
\hline Hagiografia & 4 & 6 & 0,5 \\
\hline Doutrina & 3 & 6 & 0,5 \\
\hline Orações & 2 & 5 & 0,4 \\
\hline Catecismo & 3 & 4 & 0,3 \\
\hline Oratória & 1 & 1 & 0,1 \\
\hline Liturgia & 1 & 1 & 0,1 \\
\hline Outros & [?] & 293 & 23,4 \\
\hline TOTAL & + de 400 [?] & 1.248 & $100 \%$ \\
\hline
\end{tabular}

Fonte: Dados organizados a partir da documentação consultada e de ALMEIDA, 2012, vol. 1, p. 192; vol. 2, p. $492-514$.

\footnotetext{
${ }^{44}$ ALMEIDA, 2012, vol. 2, p. 514.

${ }^{45}$ Ver: COSTA, 1965 , p. 224; p. 227-228.

${ }^{46}$ Há discrepâncias entre o total de títulos listados e o de volumes informado para a livraria de Olinda no Livro dos Inventarios dos Conventos do Norte, talvez por sua repetição na rubrica "Assuntos Diversos".
} 
Dentre tais obras de Emblemática a que apresenta mais exemplares, com cinco cópias, é justamente a principal do Pe. Filippo Picinelli, o mesmo Mundus symbolicus que também tinha três volumes na livraria da Paraíba. A peculiaridade deste livro reside no fato de ter sido concebido por seu autor como uma compilação de emblemas que desse conta de todas as possibilidades de interpretações das coisas criadas por Deus, ou seja, Picinelli entendia que o mundo podia ser lido simbolicamente como o Livro da Criação, no mesmo sentido que aquele proposto em Romanos 1:20: "Porque as Suas coisas invisíveis, desde a criação do mundo, tanto o Seu eterno poder, como a Sua divindade, se entendem, e claramente se veem pelas coisas que estão criadas, para que elas fiquem inescusáveis".

O Mundus Symbolicus era um projeto extremamente ambicioso de Picinelli e que tinha a intenção explícita de, na visão de Genoveffa Palumbo, "construir um universo simbólico real que constituísse uma espécie de mundo paralelo, um mundo cultural, grande e complexo como o mundo natural, com suas regras, seus objetos e seus limites" ${ }^{47}$. Mario Praz, em sua obra clássica sobre o universo da Emblemática na Europa barroca, ainda na década de 1930, considerava o livro do Cônego Picinelli como uma verdadeira enciclopédia de emblemas pensada para o uso prático de pregadores em seus sermões ${ }^{48}$, ou seja, uma adaptação da linguagem simbólica e alegórica barroca tão própria dos emblemas aos preceitos pós-tridentinos de persuadir pelos sentidos, de usar as imagens, de catequisar pela emotividade. Nada mais do que uma formação de ponta para os frades recémprofessos da Província de Santo Antônio do Brasil, portanto, disponibilizando numa de suas maiores livrarias conventuais tal obra de caráter referencial à época.

Fig. 7 - Folha de rosto do primeiro tomo do Mundus Symbolicus in Emblematum Universitate Formatus, do Pe. Filippo Picinelli, em edição in folio publicada em Colônia, em 1695.

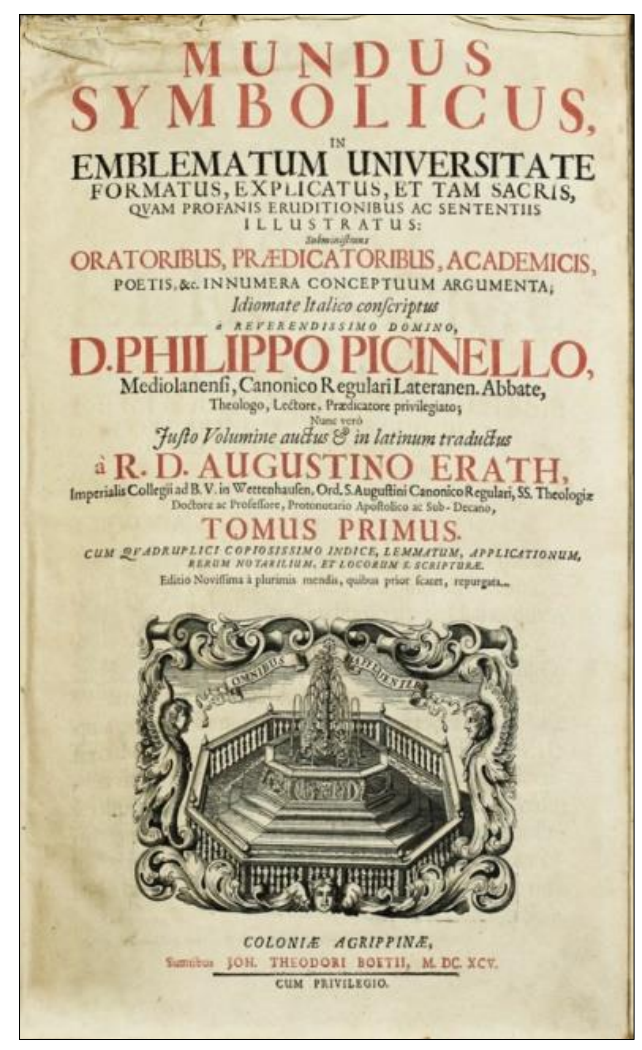

Fonte: http://books.google.com.br/.

47 PALUMBO, 2011, p. 621. O texto original: "In particolare nel Mondo simbolico, l'autore, pur avendo anch'egli di mira un fine pratico, tende soprattutto a costruire un vero e proprio universo simbolico che costituisce una sorta di mondo parallelo, un mondo culturale, grande e complesso come il mondo naturale, con le sue regole, i suoi oggetti e i suoi confini”".

${ }^{48}$ PRAZ, 2005, p. 184. 
O segundo título de Emblemática presente na livraria de Olinda é de autoria do Pe. Heinrich Engelgrave (1610-1670), S.J., religioso flamengo que foi reitor dos colégios inacianos de Oudenaarde, Kassel e Bruges ${ }^{49}$. Trata-se de Coelum Empyreum ${ }^{50}$, também conhecido por Coeleste Pantheon, que tem três exemplares no acervo em questão e trata-se de uma coletânea de sermões, organizados a partir do calendário litúrgico e tendo como motivação as festas em honra dos santos, a começar por Jesus Cristo e a Virgem Maria. Junto com o Lux Evangelica, também da autoria do Pe. Engelgrave, se constituiu em obra de relativo sucesso nos meios eclesiásticos de meados do seiscentos e por todo o setecentos - entre 1657, ano de seu lançamento, e 1727, ou seja, em sete décadas, teve pelo menos 66 edições em latim ou alemão ${ }^{51}$.

É possível atribuir a proficuidade de sua circulação entre os religiosos seculares e de diversas ordens e congregações tanto ao seu formato - pois a maior parte das edições eram in quarto, ou seja, de dimensões pensadas para um manuseio mais cotidiano - como ao fato de a obra também fornecer elementos de oratória catequética estruturados a partir da lógica da Emblemática: após uma pictura - ou mesmo uma emblemata $n u d a^{52}$ em algumas edições, como na de 1727 - seguia-se um argumentvm com um texto expondo alguns temas que logo eram desdobrados em alguns motti, além de elementos articulados em torno das festas dos santos, com detalhes da hagiografia, de trechos das escrituras, de versos latinos clássicos, de tudo que pudesse contribuir para chegar ao resultado persuasório do construto simbólico intentado por Engelgrave. Imagem e persuasão, a base da cultura barroca, portanto, travestida no discurso pós-tridentino, e servindo de substrato para a formação dos noviços e aperfeiçoamento dos frades da casa franciscana de Olinda.

Fig. 8 - Folha de rosto de Caelum Empyreum, do Pe. Heinrich Engelgrave, em edição in quarto publicada em Colônia, em 1668.

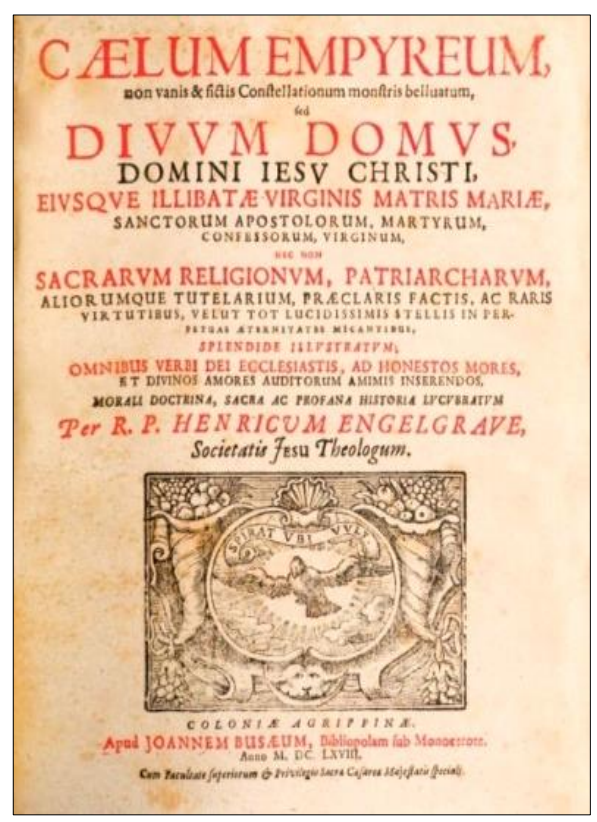

Fonte: http://books.google.com.br/.

\footnotetext{
${ }^{49}$ Informação do sítio eletrônico do Munich DigitiZation Center - Digitale Bibliothek, divisão da Bayerische StaatsBibliothek, Munique, Alemanha. Disponível em: <http://mdz1.bib-bvb.de/ emblem/emblalle.html? inpKng=paut\&inpBegriff=Engelgrave,\%20Heinrich>. Acesso em: 23 abr. 2018.

${ }^{50}$ ENGELGRAVE, 1668; 1727.

${ }^{51}$ Dados disponíveis na base do WorldCat Identities/ OCLC Online Computer Library Center. Disponível em: <http://worldcat.org/identities/lccn-nr2001035154/>. Acesso em: 01 jun. 2018.

${ }^{52}$ Emblema ou divisa sem imagem, onde a pictura é substituída por uma descrição verbal.
} 
A terceira obra de Emblemática presente no acervo da livraria olindense contava com apenas um exemplar, mas talvez seja uma das mais sofisticadas e complexas dentre todas as que fizeram parte das estantes franciscanas na Província de Santo Antonio do Brasil. Trata-se de Homo et Ejus Partes Figuratus \& Symbolicus ${ }^{53}$, do Pe. Ottavio Scarlattini (1623-1699), cônego regular lateranense e matemático ${ }^{54}$, cuja primeira edição em italiano é de 1684 . Na ilustração de frontispício de sua edição latina de 1695, publicada pelas oficinas de Johann Caspar Bencard (1649-c.1720) em Augsburgo e Dilingen, na Alemanha, a linguagem alegórica típica do Barroco e também da Emblemática junta-se aos ideais pós-tridentinos: na bela gravura de Leonhard Heckenauer (1655-1704) o topo do globo terrestre traz a representação do homem perfeito - que pode ser associado ao Adão bíblico - ladeado por dois seres colossais que sustentam uma larga tarja circular com as constelações do Zodíaco, associadas às partes do corpo humano. Sob os pés desse ser edênico barroco, uma faixa com um versículo em latim do Salmo 8 da vulgata: "Omnia subiecisti sub pedibus Ejus", ou seja, "Tudo se sujeita a teus pés". Ainda a ideia renascentista do homem como medida das coisas, mas mostrada por meio de um texto do Antigo Testamento, a tentativa de juntar uma incipiente percepção científica do mundo com as coisas da Fé, nada mais Barroco do que esse aparente paradoxo.

Fig. 9 - Folha de rosto do primeiro tomo de Homo et Ejus Partes Figuratus \& Symbolicus, do Pe. Ottavio Scarlattini, em edição in folio publicada em Augsburgo e Dilingen, nas oficinas de Johann Caspar Bencard, em 1695.

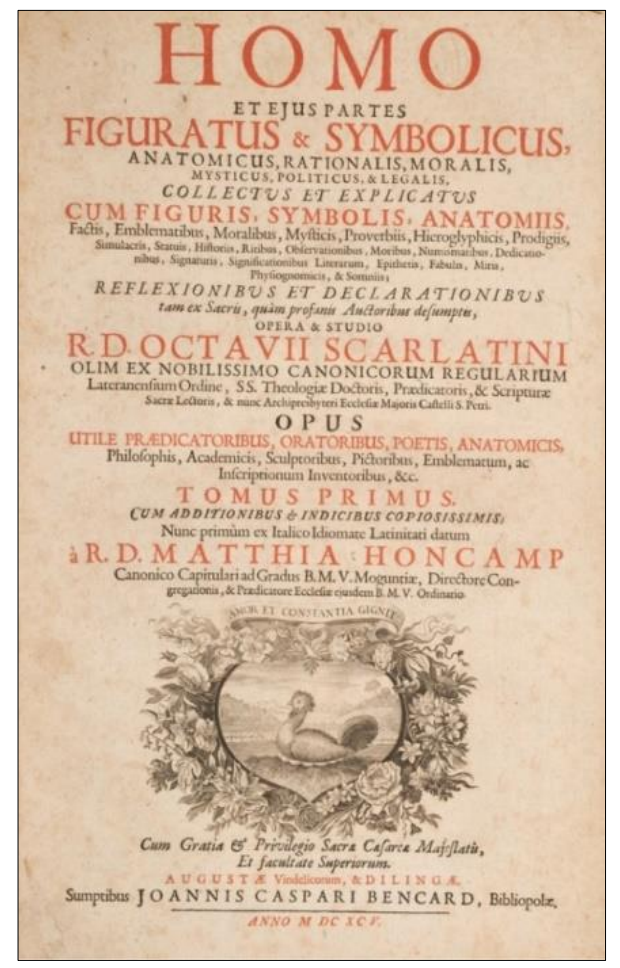

Fonte: http://archive.org/.
Fig. 10 - Leonhard Heckenauer, "Homo Figuratus et Symbolicus", 1695. Gravura a talho doce, ilustração de frontispício do primeiro tomo de Homo et Ejus Partes Figuratus \& Symbolicus, do Pe. Ottavio Scarlattini, em edição in folio publicada em Augsburgo e Dilingen, nas oficinas de Johann Caspar Bencard, em 1695.

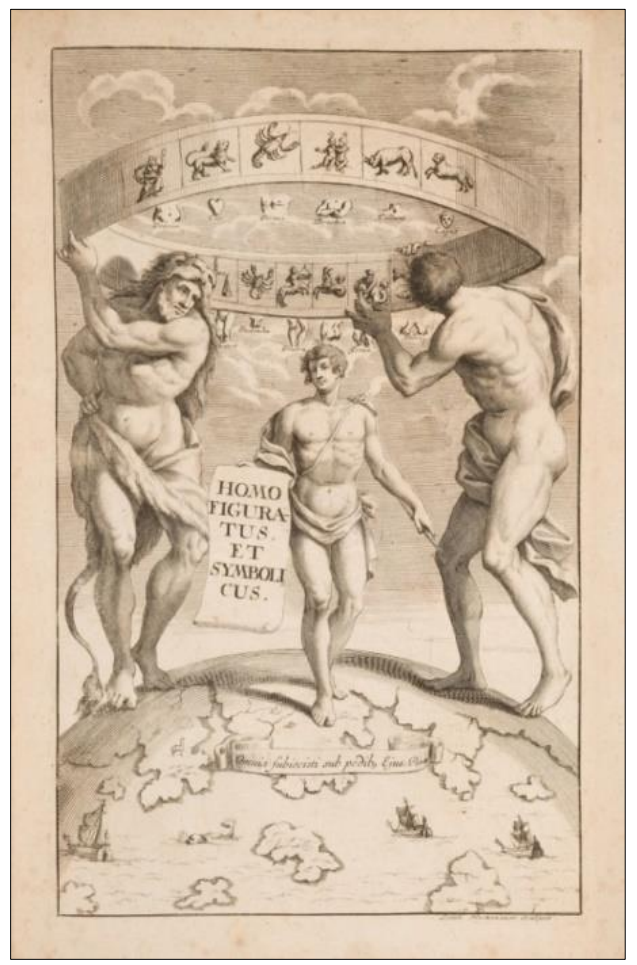

Fonte: http://archive.org/.

\footnotetext{
53 Tradução livre, aproximada, do título: "O Homem e suas Partes Figuradas e Simbólicas".

${ }^{54}$ FANTUZZI, 1789, p. 355-359.
} 
Era justamente essa edição de 1695 do Homo et Ejus Partes Figuratus \& Symbolicus que existia no acervo da livraria franciscana de Olinda ${ }^{55}$, ou seja, um volume in folio $^{56}$, de grandes dimensões e, por isso mesmo, destinado não à leitura de fruição, mas ao uso como obra de referência, na própria livraria. Dividido em dois tomos, usualmente o título era encadernado com ambos os exemplares num único volume ${ }^{57}$. Em síntese, se pode dizer que a obra conciliava o universo simbólico da Emblemática com o campo dos estudos da Teologia Moral, da nascente pesquisa médico-anatômica e ainda com impregnações das crenças místicas herdadas de práticas do medievo e de começos da Idade Moderna. No primeiro tomo são estudados os órgãos individuais do corpo humano, de acordo com a concepção da época, voltada primordialmente ao destaque dos sentidos ainda sob forte influência do ideário da medicina galeana, sempre relacionando-os a emblemas figurados: olhos, lábios, nariz, coração, ouvidos, etc. No segundo tomo são abordados aspectos gerais da moral e da vida humana, todos estes, por sua vez, relacionados com emblemata nuda.

Fig. 11 - Emblema "Revocare ad Malleum" [Trazendo de volta o Martelo], Homo et Ejus Partes Figuratus \& Symbolicus, edição de 1695, tomo1, p. 140.

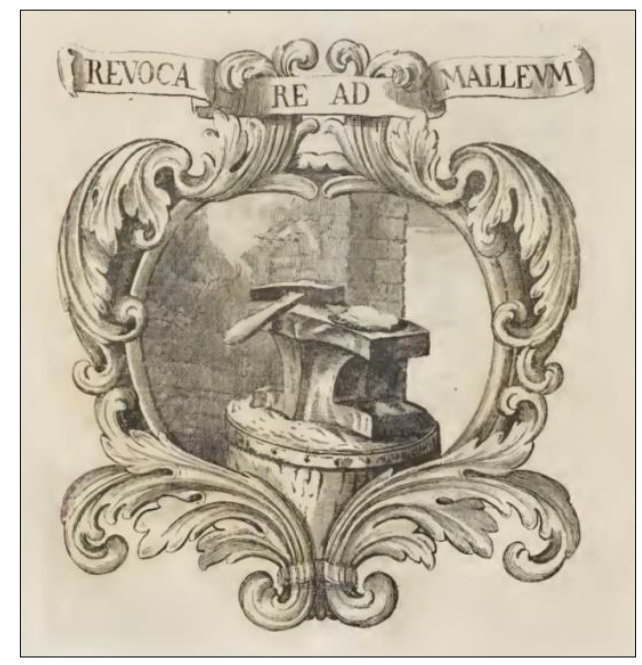

Fonte: http://archive.org/.
Fig. 12 - Emblema "Pulchram Gloriae Messem Colligo" [Bela e Rica Colheita da Glória], Homo et Ejus Partes Figuratus \& Symbolicus, edição de 1695, tomo 1, p. 184.

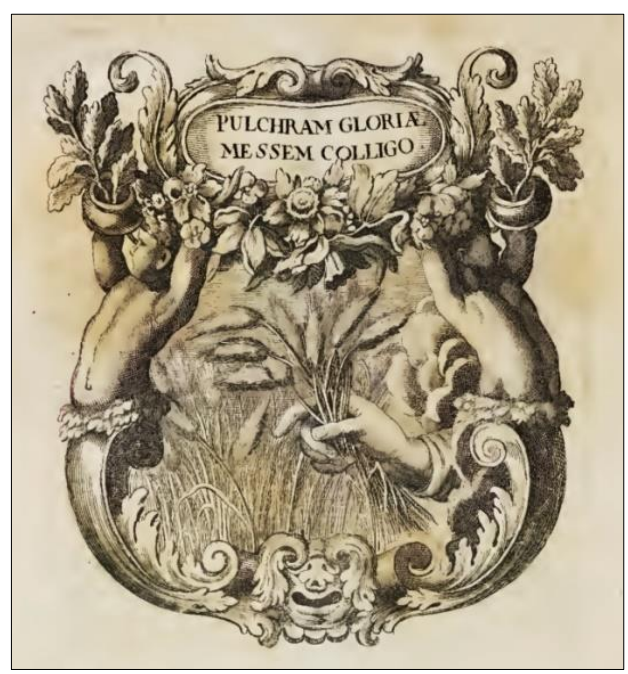

Fonte: http://archive.org/.

\section{A livraria do Convento de Santo Antônio da Vila de Igarassu}

A outra livraria franciscana de Pernambuco de que ficou registro do conteúdo de seu acervo foi a do Convento de Santo Antônio de Igarassu, casa onde os noviços entravam como postulantes e realizavam os estudos menores até o momento de professarem seus primeiros votos. Os livros disponíveis em sua livraria deveriam, essencialmente, atender às necessidades

\footnotetext{
${ }^{55}$ Em seu relatório de 1886, do qual há uma cópia manuscrita no Arquivo Provincial Franciscano do Recife, Pereira da Costa reporta que era esta a edição existente na livraria do Convento de Nossa Senhora das Neves, em Olinda (ALMEIDA, 2012, vol. 2, p. 510).

${ }^{56}$ Cerca de 22,5 cm X 35,5 cm a $24 \mathrm{~cm}$ X $37 \mathrm{~cm}$ de dimensão para as páginas dos exemplares da mesma edição digitalizados e disponibilizados nos acervos on line do Google Books, do Archive.org e da Europeana.

${ }^{57}$ É comum se encontrar essa configuração nos volumes digitalizados e disponibilizados on line, bem como naqueles que aparecem, esporadicamente, nas casas de leilão especializadas.
} 
dos mestres de Gramática Latina e dos lentes de Teologia e Filosofia que atuavam no cenóbio. Ao analisar a distribuição temática das obras que ainda existiam na livraria em 1852 e que estão listadas no Livro dos Inventarios do Fr. Machado, fica claro o foco sobre Teologia e Estudos Bíblicos, que representavam quase $40 \%$ das obras disponíveis, bem como aquelas tratando de Sermões, com $7 \%$, como seria de se esperar numa casa que abrigava as aulas de formação inicial dos noviços, com os estudos divididos entre Studia Artium, Studia Philosophiae e Studia Theologiae, englobando Retórica, Oratória, Grego, Hebraico, Gramática Latina, Teologia e Filosofia.

TABELA 3: Temas na Livraria Franciscana de Igarassu - PE (inventário de 1852 - 143 volumes)

\begin{tabular}{|ccccc}
\hline TEMAS & $\begin{array}{c}\text { NÚMERO } \\
\text { DE } \\
\text { TÍTULOS }\end{array}$ & $\begin{array}{c}\text { \% SOBRE } \\
\text { TÍTULOS }\end{array}$ & $\begin{array}{c}\text { TOTAL DE } \\
\text { VOLUMES }\end{array}$ & $\begin{array}{c}\text { \% DO } \\
\text { ACERVO }\end{array}$ \\
\hline \hline Emblemática & 2 & 4,08 & 4 & 2,8 \\
\hline Teologia \& Estudos Bíblicos & 20 & 40,81 & 54 & 37,8 \\
\hline Liturgia & 4 & 8,16 & 4 & 2,8 \\
\hline Estudos Franciscanos & 3 & 6,12 & 4 & 2,8 \\
Estudos Marianos & 3 & 6,12 & 4 & 2,8 \\
Sermões & 2 & 4,08 & 10 & 7,0 \\
Hagiografia & 1 & 2,04 & 1 & 0,7 \\
\hline História de Portugal & 1 & 2,04 & 1 & 0,7 \\
Documentos Eclesiásticos \& & 1 & 2,04 & 1 & 0,7 \\
Pontifícios & 12 & 24,48 & 60 & 41,9 \\
\hline Outros & $\mathbf{4 9}$ & $\mathbf{1 0 0 \%}$ & $\mathbf{1 4 3}$ & $\mathbf{1 0 0 \%}$ \\
\hline \hline TOTAL & & & 104 \\
\hline \hline
\end{tabular}

Fonte: Dados organizados a partir da documentação consultada e de ALMEIDA, 2012, vol. 2, p. 527-533.

Um dos dois títulos de Emblemática disponíveis em Igarassu era o Mundus Symbolicus do Pe. Picinelli, com dois volumes no acervo, o que demonstra a importância atribuída ao título pela ordem na formação dos noviços, já que ela também figurava no acervo da Paraíba e de Olinda, como já assinalei. A outra obra presente no acervo igarassuense é muito peculiar: tratase do Livre curieux et utile pour les sçavans et artistes, de Nicolas Verrien (c.1660?-c.1730?), mestre escrivão e gravador especializado em monogramas e emblemas dos mais destacados na França de Luís XIV, que atuou em Paris entre 1685 e 1724. Desse Livre curieux constava que existiram duas cópias naquela livraria.

O Livre curieux veio a lume pela primeira vez com privilégio real em 1685, recebendo uma reedição na década seguinte, em 1694 ou 1696, e uma terceira edição já em 1724, além de uma obra em cópia - que não dava crédito a Verrien - publicada em Amsterdam em 1707, todas elas impressas in octavo ${ }^{58}$, ou seja, tratava-se de obra de fácil manuseio, pensada para uso pessoal. Sua presença numa casa franciscana em que se iniciava a formação religiosa dos postulantes é bem significativa, pois a obra era, antes de tudo, um pequeno catálogo de modelos de emblemas, ou seja, uma obra de referência e consulta, mas que também fornecia ideias para a criação de alegorias imagéticas, fossem elas visuais ou discursivas. No âmbito da cultura persuasiva do Barroco, sem dúvida tratava-se de manual dos mais sofisticados do campo da Emblemática para figurar numa livraria, fosse ela religiosa ou laica.

\footnotetext{
${ }^{58}$ Dados disponíveis na base do WorldCat Identities/ OCLC Online Computer Library Center. Disponível em: <http://www.worldcat.org/identities/lccn-nr00005637/>. Acesso em: 13 jun. 2018.
} 
Fig. 13 - Folha de rosto da edição de 1685 do Livre curieux et utile pour les sçavans et artistes, de Nicolas Verrien, publicado em Paris, com privilégio real.

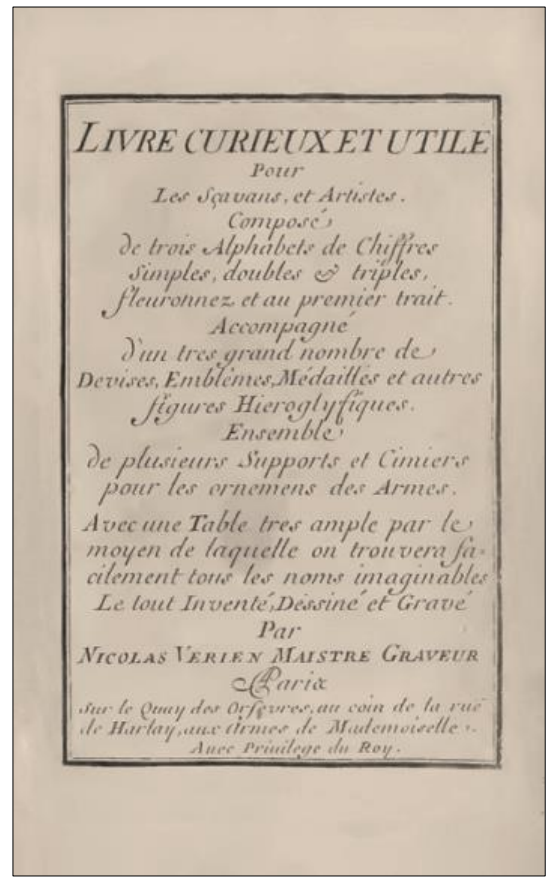

Fonte: http://archive.org/.
Fig. 14 - Primeira página de emblemas do Livre curieux et utile pour les sçavans et artistes, de Nicolas Verrien, em sua edição de 1685 , com a respectiva explicação das alegorias na página seguinte.

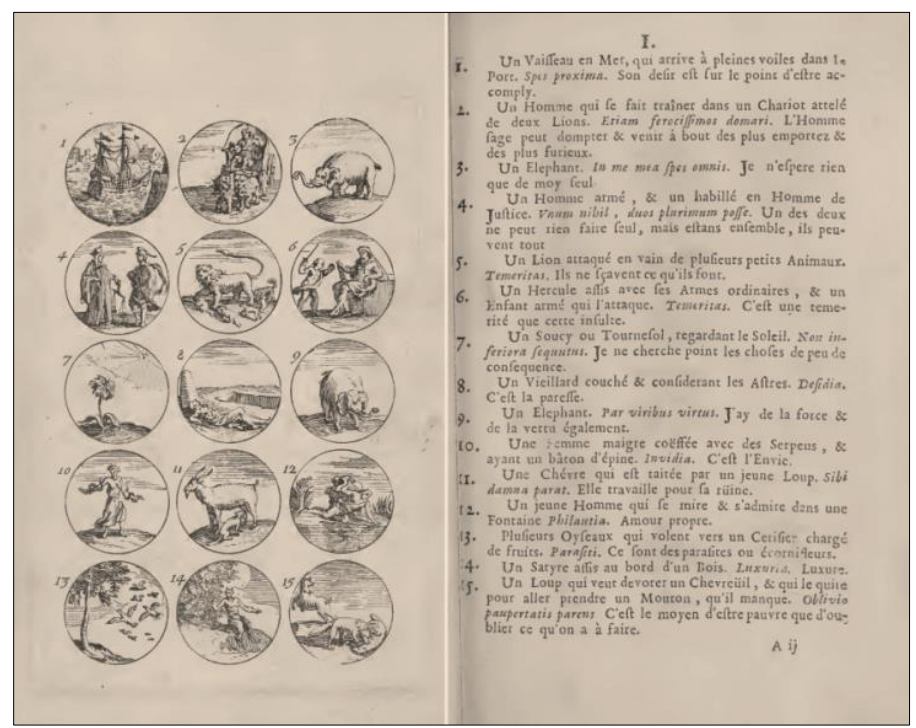

Fonte: http://archive.org/.

Por meio das imagens do Livre curieux os noviços do convento de Igarassu podiam aprender a treinar seu olhar para identificar as analogias simbólicas embutidas nos emblemas, e do mesmo modo, utilizá-las para construir novas metáforas visuais em seus exercícios de Oratória. Trata-se de artifício dos mais interessantes para a fixação e naturalização de uma linguagem tão complexa e cheia de erudição como a da Emblemática, sem dúvida, mas parece que, dada a qualidade das obras deste tipo adquiridas pelos seráficos para suas livrarias, havia de fato uma preocupação em utilizá-las em sua Pedagogia cotidianamente.

\section{A livraria do Convento de Santo Antônio da cidade da Paraíba}

Por fim, chegamos ao último acervo registrado no Livro dos Inventarios do Fr. Machado em 1852, o do Convento de Santo Antônio da Paraíba. Com um total de 78 títulos e 184 volumes, as dimensões do acervo paraibano não chegavam a diferir muito do existente na livraria de Igarassu, embora a superasse em mais de 40 volumes e 30 títulos, o que talvez possa ser explicado pela distância em relação ao teatro mais dramático dos conflitos armados da Restauração Pernambucana, em meados do seiscentos, e ao fato de os frades terem abandonado o convento da Paraíba durante a ocupação holandesa e resguardado o acervo da livraria em local seguro, evitando a perda de obras do período anterior à presença batava, o que pode não ter acontecido em Igarassu já que, certamente, não ocorreu em Ipojuca, como se verá mais à frente. 
TABELA 4: Temas na Livraria Franciscana da Paraíba - PB (inventário de 1852 - 184 volumes)

\begin{tabular}{|ccccc}
\hline \hline TEMAS & $\begin{array}{c}\text { NÚMERO } \\
\text { DE } \\
\text { TÍTULOS }\end{array}$ & $\begin{array}{c}\text { \% SOBRE } \\
\text { TÍTULOS }\end{array}$ & $\begin{array}{c}\text { TOTAL DE } \\
\text { VOLUMES }\end{array}$ & $\begin{array}{c}\text { \% DO } \\
\text { ACERVO }\end{array}$ \\
\hline Emblemática & 2 & 2,6 & 5 & 2,7 \\
Teologia \& Estudos Bíblicos & 35 & 44,9 & 74 & 40,2 \\
Direito Canônico & 8 & 10,3 & 16 & 8,7 \\
Bíblia & 1 & 1,3 & 13 & 7,1 \\
Estudos Marianos & 4 & 5,2 & 12 & 6,5 \\
Documentos Eclesiásticos \& & 2 & 2,6 & 11 & 6,0 \\
Pontifícios & 3 & 3,8 & 8 & 4,3 \\
Filosofia & 8 & 10,3 & 8 & 4,3 \\
Liturgia & 2 & 2,6 & 5 & 2,7 \\
Sermões & 2 & 2,6 & 5 & 2,7 \\
\hline Doutrina Cristã & 2 & 2,6 & 3 & 1,6 \\
\hline Estudos Franciscanos & 1 & 1,3 & 2 & 1,1 \\
\hline Dicionário & 1 & 1,3 & 1 & 0,5 \\
\hline História Eclesiástica & 7 & 9,0 & 21 & 11,4 \\
\hline Outros & $\mathbf{7 8}$ & $\mathbf{1 0 0 \%}$ & $\mathbf{1 8 4}$ & $\mathbf{1 0 0 \%}$ \\
\hline TOTAL & & & & \\
\hline \hline
\end{tabular}

Fonte: dados organizados a partir da documentação consultada e de ALMEIDA, 2012, vol. 2, p. 515-526.

Ou talvez o fato determinante para essa diferença seja que já nos primeiros anos da Custódia se instalou naquele cenóbio uma classe de Gramática Latina destinada aos postulantes e também aos filhos dos moradores e, assim, apesar de costumeiramente não abrigar estudos menores de Teologia ou Filosofia, nos Estatutos provinciais de 1709 - que em diversos aspectos repetiam as determinações do documento congênere de 1683 - ficara estabelecido o funcionamento de uma Magister Grammatica permanente na casa paraibana:

Para que os Estudantes, q haõ de ir à Filosofia, sejam bons Grammaticos, ordenamos que no Convento de nosso Padre S. Francisco da Cidade da Paraiba haja estudo de Grammatica, pois he o fundamento de todas as mais sciencias; para o qual elegerà o Irmaõ Ministro quando for em visita dès, ou doze Religiosos, que vir tem genio, $\&$ habilidade para as mais sciencias; \& para Mestre do ditto estudo de Grammatica escolherá de toda a Provincia o Religioso, que estiver mais bem visto nella, para que da sua explicaçaõ se aproveytem os discipulos; ao qual Mestre izentamos de todo o Coro \& obrigações do Convento. ${ }^{59}$

Dada a responsabilidade do ensino de Gramática Latina aos postulantes, há também de se considerar a qualidade do acervo da livraria paraibana, portanto. Nele aparecem dois exemplares do Suplemento ao Vocabulario Portuguez e Latino do Pe. Raphael Bluteau, o que seria de se esperar numa casa onde a instrução aos noviços tinha esse perfil. Assim como nas outras livrarias, destacam-se no acervo paraibano as obras de Teologia e estudos bíblicos, com mais de $40 \%$ dos títulos e volumes de suas estantes. As obras de Emblemática representam

${ }^{59}$ ESTATUTOS, 1709, p. 31. 
apenas 2,7\% do acervo, com cinco volumes e dois títulos: um deles era, como já me referi, o Mundus Symbolicus do Pe. Piccinelli, com três exemplares; os outros dois volumes eram de um título que teve nada menos do que 115 edições entre 1648 e $1750^{60}$, o Lux Evangelica sub Velum Sacrorum Emblematum Recondita in Anni Dominicas, do Pe. Heinrich Engelgrave, S.J.

Fig. 15 - Folha de rosto da edição de 1648 do Lux Evangelica Sub Velum Sacrorum Emblematum Recondita in anni Dominicas, do Pe. Heinrich Engelgrave, S.J., publicado em Antuérpia, nas oficinas da viúva e herdeiros de Jan Cnobbaert.

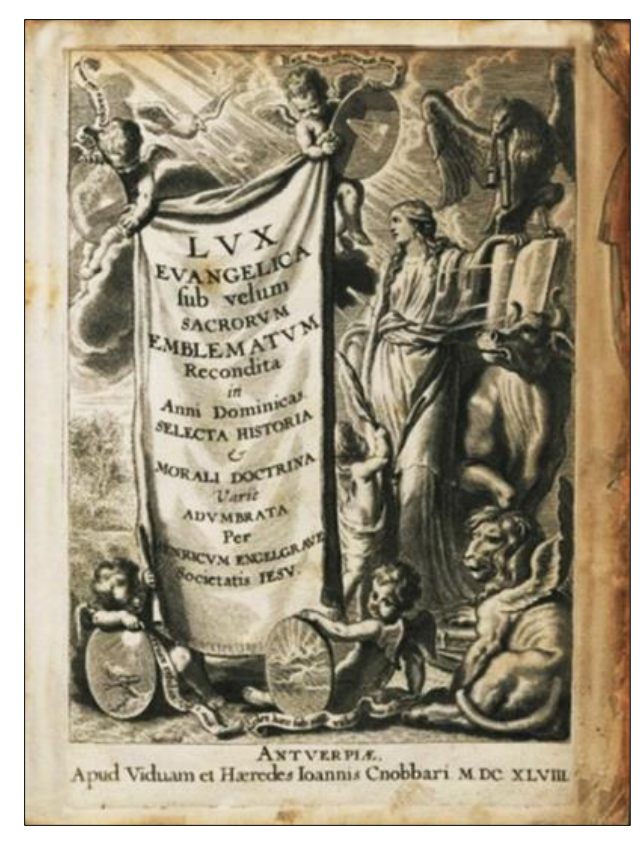

Fonte: http://www.flandrica.be/.
Fig. 16 - Emblema LII "Non Canimus Surdis" [Não Cantemos para os Surdos], referente ao $24^{\circ}$ domingo do tempo comum, após o Pentecostes, Lux Evangelica Sub Velum Sacrorum Emblematum Recondita in anni Dominicas, edição de 1648, tomo 1, p. 463.

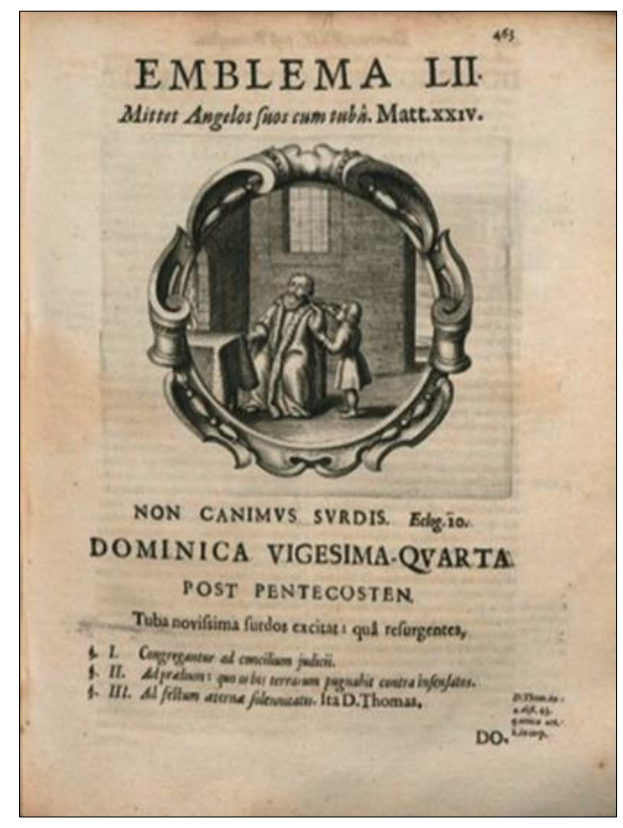

Fonte: http://www.flandrica.be/.

O Lux Evangelica teve edições em diversos centros tipográficos europeus proeminentes do seiscentos e do setecentos, como Amsterdam, Antuérpia e Colônia, aparecendo em diferentes configurações, em formato in quarto ou in octavo, mas sempre dividido em dois tomos. O primeiro deles contém 52 sermões distribuídos pelos domingos do ano, precedidos por um ensaio geral. Os emblemas que precedem cada um dos sermões são reproduzidos em várias edições como emblemata nuda, ou seja, sem a pictura. Nas edições ilustradas, cada pictura é anexada a dois motti: o primeiro é um texto bíblico, o segundo é um trecho da literatura clássica, geralmente latina. Logo em seguida vem a indicação da festa ou tema daquele domingo em particular, depois é apresentado um pequeno extrato do tratado que será desenvolvido mais à frente. Segue-se a descrição da pictura, e neste trecho se constrói habilmente a conexão entre o emblema e o sermão, entre a alegoria e a oratória cristã, entre todo um universo de símbolos e a persuasão barroca.

Foi sobre este amálgama entre pictura e motti e sua argumentação que o Pe. Engelgrave construiu habilmente todo um discurso em prosa explicando os textos sagrados que servia como

\footnotetext{
${ }^{60}$ Dados disponíveis na base do WorldCat Identities/ OCLC Online Computer Library Center. Disponível em: <http://www.worldcat.org/identities/lccn-nr2001035154/>. Acesso em: 01 jun. 2018.
} 
inspiração para os sacerdotes se prepararem para o exercício das prédicas em suas funções cotidianas nas diversas missas que conduziam. A proposta do Lux Evangelica se acostava no modelo já consolidado, então, de formação dos jesuítas com uso da Emblemática como preparação para a arte da homilética ${ }^{61}$ : num mundo católico em que o letramento ainda era baixo - ao contrário do que ia se conformando nos espaços de expansão do protestantismo - a oratória era essencial para a transmissão das ideias religiosas e propagação da Fé católica. Nesse sentido, o fato de Engelgrave ter sido reitor de três colégios jesuíticos no sul dos Países Baixos certamente o preparou muito bem para adequar sua obra às intenções formativas da Companhia de Jesus e da Ratio Studiorum, que outras congregações e ordens religiosas católicas adaptavam ao utilizar seu livro de Emblemática na instrução de seus seminaristas, postulantes e noviços. Os emblemas da primeira edição, publicada em Antuérpia, ficaram a cargo de Hendrik Snyders, gravador ali atuante em meados do seiscentos, e foram reproduzidos nas edições seguintes, mesmo quando ocorria alguma repaginação ou se modificava a apresentação do texto de uma para duas colunas. O segundo tomo da obra segue o mesmo esquema do primeiro nas edições ilustradas, mas é dedicado especialmente às festas do ano litúrgico e aos santos da Igreja e à Virgem Maria ${ }^{62}$.

\section{Inferências possíveis: ao modo de um arremate?}

Tentar reconstituir o acervo e dimensionar o alcance das livrarias da Província Franciscana de Santo Antônio do Brasil obviamente são desafios que nunca poderão ser plenamente alcançados, por diversos motivos, a começar pela tragédia que representou a destruição inexorável de tantas preciosidades que as estantes de todos os treze conventos da Província deveriam abrigar no setecentos, já que mesmo as casas onde não se desenvolviam cotidianamente os estudos menores ou maiores ou as classes fixas de Gramática Latina deveriam, por força dos Estatutos Provinciais, dispor de um espaço para abrigar os livros e servir para as horas de estudo dos frades ${ }^{63}$. Se apenas com a descrição temática do acervo das livrarias de quatro daqueles conventos e focando suas obras de Emblemática já é possível tecer algumas inferências bem significativas a respeito de tais espaços de leitura, de sua relação com a Pedagogia Seráfica e, mais ainda, da importância dessas obras de Emblemática para a instrução básica e aprimoramento teológico e filosófico dos frades, desde o noviciado e mesmo depois de já professos, que pensar então se porventura soubéssemos que títulos existiam nas livrarias das outras casas franciscanas?

As livrarias e o mundo dos livros constituíam um universo imprescindível ao embasamento da práxis franciscana no século, isso já foi discutido por diversos autores no que se refere ao cenário europeu ${ }^{64} \mathrm{e}$, claramente, se mostra como uma característica também presente entre os seráficos observantes que se instalaram na América portuguesa. Dos grossos

\footnotetext{
${ }^{61}$ PRAZ, 2005, p. 219-222.

${ }^{62}$ ENGELGRAVE, 1648, 1654, 1655a, 1655b.

63 “Todas as nossas cazas tenham livrarias, de que haverá inventario, \& dos livros que nelas estão, dará conta o q assistir na livraria, para o que terá o tal Religioso a chave della, \& o Guardião terá cuydado de mandar concertar os livros, para que senão percam; \& se indo o Irmão Ministro, ou Visitador visitar a livraria de algum Convento, achar alguns livros rotos, desencardenados, \& sem capas, os mandará logo concertar, \& suspenderá o Guardião da caza por dous mezes em pena de os não ter mandado concertar antes que se visitasse o Convento" (ESTATUTOS, 1709, p. 137).

${ }^{64}$ Ver: BÉRIOU, MORARD \& DALLA GUARDA, 2014; JONES, 1974; KRIEGER, 1995; MOORMAN, 1968; ŞENOCAK, 2003, 2004, 2012a, 2012b; ROEST, 2000, 2004, 2015; VERA, 2013.
} 
volumes de Teologia, de Estudos Bíblicos, de Filosofia, de Estudos Marianos e Franciscanos, de Hagiografia, de Liturgia, de Doutrina Cristã e Oratória vinham as bases teóricas para a ação catequética, enquanto que das obras de Emblemática, sem dúvida, vinham o refinamento e a erudição para capacitar os frades na construção de imagens cheias de persuasão, fossem elas de fato cristalizadas em obras de cantaria ou talha de madeira, ou então em ágeis pinceladas em retábulos, medalhões, painéis e tetos espalhados pelos conventos da Província - posto que mesmo que não executassem diretamente tais peças, os frades as encomendavam e estabeleciam seus planos de execução - ou em sermões que eram pérolas de oratória barroca e dos quais restaram pouquíssimos registros até nossos dias.

Na tabela 5 é possível observar a distribuição das obras de Emblemática pelas livrarias aqui analisadas de forma panorâmica e fica claro que, se mesmo em conventos de menor projeção, como as casas de Igarassu e da Paraíba, tais obras estavam presentes, e se nos cenóbios de Olinda e Salvador, onde se davam os estudos maiores dos jovens frades professos, e de modo mais evidente em Pernambuco, se tem registro certo da existência de uma variedade maior destes títulos, obviamente os franciscanos atribuíam certa importância a esta temática para a formação e erudição de seus frades. O fato de os emblemas do Theatro Moral terem sido escolhidos para decorar os azulejos do claustro do convento soteropolitano só reforçam este entendimento.

TABELA 5: Obras de emblemática nas Livrarias Franciscanas, Província de Santo Antônio do Brasil - BA/PE/PB - Século XVIII

\begin{tabular}{ccccc}
\hline \hline OBRAS & $\begin{array}{c}\text { CONVENTO } \\
\text { DE } \\
\text { SALVADOR }\end{array}$ & $\begin{array}{c}\text { CONVENTO } \\
\text { DE OLINDA }\end{array}$ & $\begin{array}{c}\text { CONVENTO } \\
\text { DE } \\
\text { IGARASSU }\end{array}$ & $\begin{array}{c}\text { CONVENTO } \\
\text { DA } \\
\text { PARAÍBA }\end{array}$ \\
\hline Theatro Moral de la Vida & 2 & - & - & - \\
Humana & - & 5 & 2 & 3 \\
Mundus Symbolicus & - & 1 & - & - \\
Homo et Ejus Partes & - & 3 & - & - \\
Caelum Empyreum & - & - & - & 2 \\
Lux Evangelica & - & - & 2 & - \\
\hline Livre Curieux & $\mathbf{2}$ & $\mathbf{9}$ & $\mathbf{4}$ & $\mathbf{5}$ \\
\hline TOTAL DE & EXEMPLARES & & & \\
\hline \hline
\end{tabular}

Fonte: Dados organizados a partir da documentação consultada e de ALMEIDA, 2012, vol. 2, p. 482-533.

Na livraria do Convento de Nossa Senhora das Neves também havia ao menos dois volumes de uma obra muito interessante, que não era de Emblemática, mas que resume bem o sentido dos livros e das bibliotecas no universo seráfico em sua ilustração de frontispício. Tratase de Bibliotheca Universa Franciscana, do Fr. Juan de San Antonio (OFM), também conhecido como Juan de Soto (1667-1736) ${ }^{65}$.

A obra de Soto pretendia dar conta de biografar, mesmo que brevemente, todos os autores franciscanos nascidos até a data de sua publicação em Madri, o ano de 1732 para os dois primeiros tomos, e de 1733 para o terceiro. Apresentado em formato de grandes dimensões,

\footnotetext{
${ }^{65}$ Dados disponíveis na base do WorldCat Identities/ OCLC Online Computer Library Center. Disponível em: <http://worldcat.org/identities/viaf-306440157/>. Acesso em: 13 jun. 2018.
} 
in folio, era livro de referência, ou seja, pensado para manuseio e consulta ocasional, e seu ambiente natural de uso eram as livrarias, certamente. Mas voltando à gravura do frontispício de seu primeiro tomo, ali se pode ver a idealização da livraria desejável no mundo seráfico: o patriarca da ordem, alado, com as mesma asas do serafim que lhe imprimiu os estigmas, repousa sobre um globo terrestre estilizado, e este por sua vez é apresentado circundado pelos assuntos de interesse dos autores franciscanos, praticamente um inventário dos temas presentes nas estantes das livrarias conventuais: "Res Biblicæ, Expositiva, Dogmatica, Escholastica, Mystica, Ascetica, Moralia, Concionatoria, Cathechistica, Regularia, Philosopiica, Christifera, Mariana, Juridica, Politica, Mathematica, Historia, Medica, Astrologia, Pœtica, Grammatica, Varia”. Envolvendo o globo, uma exortação à atenção às leis e escrituras, com uma referência final a um trecho da vulgata, o segundo capítulo do Segundo Livro dos Macabeus, onde se admoesta o cuidado com os livros e sua conservação. Além disso, todo o globo aparece povoado por olhos e penas de escrever, possivelmente numa representação alegórica do olhar e da escrita franciscanos espalhados pelo orbe.

Saindo dos lábios de São Francisco, como era comum nas representações barrocas, fitas representam sua fala, contendo uma variante de outro trecho da vulgata, o Salmo 18, iniciando por seu $5^{\circ}$ versículo: "In omnem terram exivit", ou seja, "Foi pregado por toda a Terra". Ao excerto do Salmo 18 se agregam referências à Regula Bulata e à missionação e catequese praticadas pelo próprio poverello d'Assisi.

Fig. 17 - Fr. Matías de Irala Yuso, "Funiculus Triplex Dificile Rumpitur" [É Difícil Romper o Cordão de Três Nós], imagem do frontispício de Bibliotheca Universa Franciscana, de Fr. Juan de Soto, tomo primeiro, Madri, 1732. Gravura a talho doce; 29,2 X 18,7 cm.

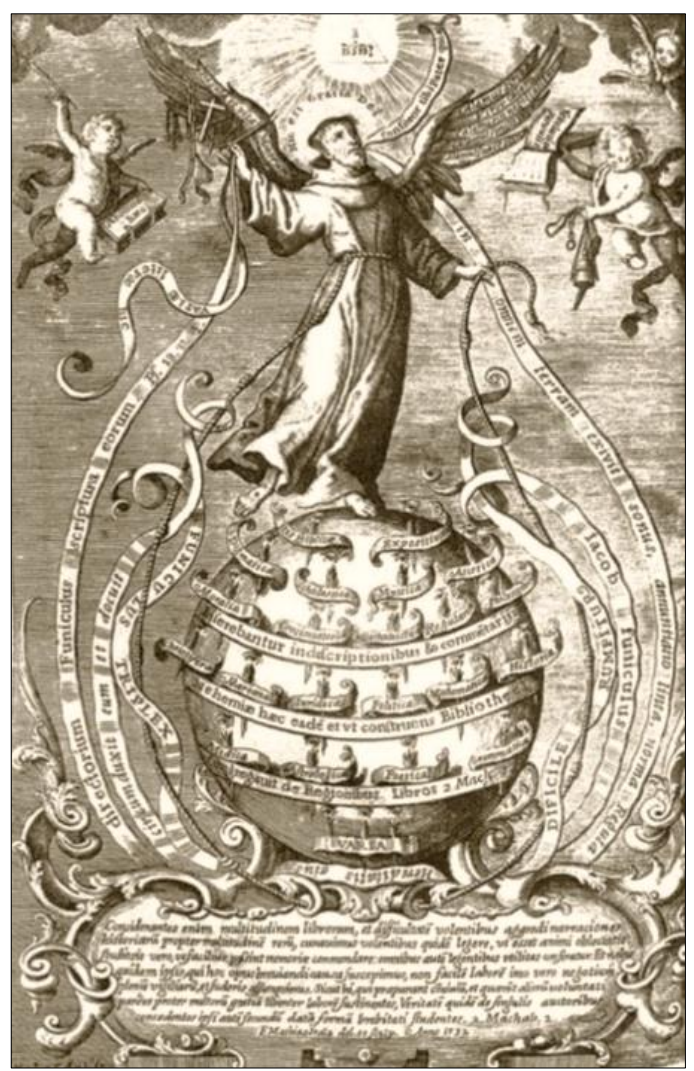

Fonte: http://bdh.bne.es/. 
As quatro livrarias franciscanas aqui apresentadas brevemente, e mais ainda, o recorte que escolhi, de adentrar seu universo de estudo e erudição por um conjunto de obras que eram típicas da cultura do Barroco, ou seja, os livros de Emblemática e sua linguagem simbólica e quase sempre hermética, que remetia a chaves de decifração muitas vezes relacionadas a elementos da cultura clássica externos ao universo católico, demonstram, no meu entendimento, quão sofisticada podia ser a Pedagogia Seráfica praticada na América Portuguesa, mesmo sem que aqui tenham se instalado os tão famosos Studia Generalia ${ }^{66}$ franciscanos que funcionavam agregados às universidades europeias.

Era certamente por meio dos livros presentes nos acervos destas livrarias, e não apenas os de Emblemática, que circulavam saberes entre o além-mar e as colônias, mesmo que houvesse a proibição explícita, nos Estatutos de 1709, de que se emprestasse ou retirasse obras de um convento a outro dentro da Província ${ }^{67}$. Talvez a determinação tenha surgido justamente pelo tráfego cotidiano de obras entre os cenóbios sem o devido controle e registro, o que deve ter causado o extravio de alguns volumes, pois em meados do seiscentos há referência não apenas ao tamanho da livraria da casa de Ipojuca, mas também à circulação de livros entre ela e o convento da Paraíba:

Acharam-se nesta livraria 190 livros, digo 200 livros com os pequenos. Entre os quais as glosas ordinárias entram em seis volumes, as partes de sagrada teologia em cinco volumes, as obras de St. Agostino em cinco volumes, as obras de São Bernardo em dois, o Incógnito, as obras de Moral de Diana em dois volumes grandes. Dêstes livros consta esta livraria do convento de St. ${ }^{\circ}$ Antônio de Ipojuca. Da casa da Paraíba estão nesta onze livros; os mais dêste convento como dos mais se perderam com os sucessos da guerra. E por verdade, me assino hoje aos 24 dias do mês de abril de 1648. (Assi) Frei Jácome da Purificação, comissário visitador. Frei Masseu de S. Francisco, secretário. ${ }^{6}$

Se em meados do século XVII a livraria do convento de Ipojuca contabilizava duzentos volumes já depois da invasão da Companhia das Índias Ocidentais e das batalhas da Restauração Pernambucana para expulsar os holandeses, é de se esperar que no setecentos seu acervo fosse maior, considerando-se as normas de constante provimento e cuidado com os livros que os guardiões das casas seráficas deviam seguir já desde o período da Custódia, como era costume entre os franciscanos. Se não é mais possível saber qual era o conteúdo das estantes ipojucanas, podemos ao menos imaginar a riqueza daquilo que irremediavelmente se perdeu, a partir deste breve relato do frei visitador, datado de meados do seiscentos. Muito provavelmente também havia, naquele cenóbio, algum título cujas páginas eram adornadas por emblemas.

${ }^{66}$ A este respeito, ver: ROEST, 2000 \& 2015; ŞENOCAK, 2012 b.

67 “E advirtam os Religiosos que por Decreto do senhor Papa Pio V. \& Sixto V. incorre ipso facto em excommunhão mayor o que furtou, ou por qualquer modo alienou livro das nossas livrarias, a qual excommunhão he reservada à Sé Apostolica, \& naõ póde ser absolto sem primeyro satisfazer o dano; \& assim ordenamos que nenhum Frade possa emprestar livro da livraria fóra da Ordem sem licença expressa do Prelado mayor, \& em sua falta do Prelado do Convento" (ESTATUTOS, 1709, p. 138).

${ }^{68}$ Apud WILLEKE, 1956, p. 321-322. Grifos meus. 
Isso porquê creio que foram mesmo os livros de Emblemática, no meu entendimento, os grandes responsáveis pela cristalização da erudição alegórica presente na decoração barroca de todos os conventos da Província de Santo Antônio do Brasil. Ao escolher os temas e formas para representá-los, definir quais atributos e elementos simbólicos a agregar às imagens sacras ou mesmo aos simples elementos decorativos, remetendo às obras de Emblemática de suas livrarias, às vezes de forma mais explícita, por outras vezes de forma mais velada, os frades estavam transpondo para a visualidade uma concepção de estar-no-mundo que se entendia como profundamente amalgamada ao sagrado, uma maneira de se por no cotidiano que era extremamente barroca e, por isso mesmo, atualíssima no setecentos.

É nas obras de Emblemática que se encontra facilmente esta simbologia, e os conventos da Província de Santo Antônio do Brasil tinham não somente um acervo significativo delas, a se pensar a realidade das livrarias no século XVIII tanto nas Américas como mesmo na Europa, mas também possuíam os títulos mais conceituados, mesmo que fossem poucos em variedade - apenas seis títulos. Eram o que hoje chamaríamos de best sellers, como o Lux Evangelica do Pe. Engelgrave, com suas mais de 115 edições, por exemplo. Afinal de contas parece que a América, ao menos neste quesito, não estava colocada assim tão na periferia do Império como já se chegou a pensar...

\section{Fontes}

ALCIATI, Andreae. Emblematvm Libellvs. Paris: Excudebat Christianus Wechlus, sub scuto Basilaensi, in vico Iacobaeo, Anno MDXXXIIII [1534]. Disponível em: <http://www.archive.org/>. Acesso em: 02 nov. 2009.

ATAS Capitulares da Província Franciscana de Santo Antônio do Brasil (1649-1893). Com introdução e notas de Fr. Venâncio Willeke, OFM. Revista do Instituto Histórico e Geográfico Brasileiro, Rio de Janeiro, vol. 286, jan./mar. 1970, p. 92-222.

COLONNA, Francesco [atribuído]. Hypnerotomachia Poliphili, ubi humana omnia non nisi somnium esse ostendit, atque obiter plurima scitu sanequam digna commemorat. [Veneza]: [Aldus Manutius], 1499. Exemplar do acervo da Library of Congress, Rare Book and Special Collection Division. Disponível em: <http://www.rarebookroom.org/>. Acesso em: 21 abr. 2012.

DICCIONARIO da Lingua Portugueza composto pelo Padre D. Rafael Bluteau, reformado, e accrescentado por Antonio de Moraes Silva natural do Rio de Janeiro. Tomo Primeiro. A = K. Lisboa: Na Officina de Simão Thaddeo Ferreira, Anno MDCCLXXXIX [1789]. Disponível em: < https://digital.bbm.usp.br/>. Acesso em: 19 fev. 2016.

ENGELGRAVE, Pe. Heinrich (SJ). Lux Evangelica sub Velum Sacrorvm Emblematvm Recondita in Anni Dominicas Selecta Doctrina Variè Advmbrata. Antuérpia: Apud Viduam \& Haeredes Ioannis Cnobbari, 1648. Disponível em: <http://www.flandrica.be/>. Acesso em: 18 jun. 2018.

ENGELGRAVE, Pe. Heinrich (SJ).. Lux Evangelica sub Velum Sacrorvm Emblematvm Recondita in Anni Dominicas Selecta Doctrina Variè Advmbrata - Altera Pars. Antuérpia: Apud Viduam \& Haeredes Ioannis Cnobbari, 1654. Disponível em: 〈http://www.archive.org/>. Acesso em: 25 abr. 2018. 
ENGELGRAVE, Pe. Heinrich (SJ). Lux Evangelica sub Velum Sacrorvm Emblematvm Recondita in Anni Dominicas Selecta Doctrina Variè Advmbrata - P. I. Colônia: Prostant Apud Iacobum à Meurs Amstelodami, 1655a. Disponível em: <http://books.google.com.br/>. Acesso em: 08 abr. 2018.

ENGELGRAVE, Pe. Heinrich (SJ). Lux Evangelica sub Velum Sacrorvm Emblematvm Recondita in Anni Dominicas Selecta Doctrina Variè Advmbrata - P. II. Colônia: Prostant Apud Iacobum à Meurs Amstelodami, 1655b. Disponível em: <http://www.archive.org/>. Acesso em: 08 abr. 2018.

ENGELGRAVE, Pe. Heinrich (SJ). Caelum empyreum, non vanis et fictis Constellationum monstris belluatum, sed divum domus, Domini Jesu Christi e jusque illibatae Virginis matris Mariae, sanctorum apostolorum, martyrum, Confessorum, virginum, nec non sacrarum religionum, patriarcharum aliorumque tutelarium praeclaris factis, ac raris virtutibus, velut tot lucidissimis Stellis in perpetuas aeternitates micantibus splendide illustratum. Colônia: Apud Ioannem Buaeum, Anno MDCLXVIII [1668]. Disponível em: 〈http://books.google.com.br/>. Acesso em: 27 abr. 2018.

ENGELGRAVE, Pe. Heinrich (SJ). Caelum empyreum, non variis \& fictis constellationum monstris belluatum; sed divorum domus, Domini Jesu Christi \& jusque illibata Virginis matris Maria, Sanctorum Apostolorum, Martyrum, Confessorum, Virginum; Nec - non sacrarum religionum patriarcharum aliorúmque Tutelarium praclaris factis, ac raris Virtutibus, velut tot lucidissimis Stellis in perpetuas aternitates micantibus splendidè illustratum. Colônia: Hærid. Thomæ von Cöllin \& Josephi Huisch, 1727. Disponível em: 〈http://books.google.com.br/>. Acesso em: 27 abr. 2018.

ESTATVTOS da Provincia de Santo Antonio do Brasil: Confirmados, Auctoritate Apostolica, em virtud e Domotu Proprio do Senhor Papa Innocencio X concedido ao Reverendissimo Padre Ministro Geral, Frey Joseph Ximenes Samaniego e mais breves aceytos nesta provincia para guarda, estabelidade, \& firmesa, destes Estatutos. Tirados de varios Estatutos da Ordem, acrecentando nelles o mais util, \& necessario, á esta nossa Provincia, Feytos, \& ordenados, neste Capitulo, que se celebrou nesta Casa de Nossa Senhora das Neves da Cidade de Marim no anno de 1681 Em que foy nomeado Provincial desta Provincia o R. P. Fr. Miguel das Chagas Prègador, Filho da Provincia de Santo Antonio de Portugal. Em Lisboa: Por Antonio Craesbeeck de Mello, Impressor da Casa Real, MDCLXXXIII [1683].

ESTATUTOS da Provincia de S. Antonio do Brasil Tirados de varios Estatutos da Ordem, accrescentando nelles o mais util, \& necessario, à reforma desta nossa Provincia, feytos, ordenados, \& aceytos no Capitulo, que se celebrou na caza de N. P. S. Francisco da Cidade da Bahia aos 14 de Fevereiro de 1705, em q foy eleyto Ministro Provincial o Irmão Prégador, \& ExCustodio Frey Cosme do Espirito Santo, filho desta Provincia, e outra vez aceytos em o seguinte capitulo, que se celebrou em o Convento de Santo Antonio de Seregippe do Conde aos 3 de Janeyro de 1708, em que foy eleyto Ministro Provincial o Irmão Prégador Frey Estevam de Santa Maria, filho da mesma Provinca, confirmados Auctoritate Apostoloca pelo eminentissimo Senhor Dom Miguel Angelo Conti, Nuncio Apostolico nestes reynos, cardial da Santa Igreja Romana, com vezes de Geral da Ordem em Portugal, dados á estampa pelo Irmão Fr. Gonsalo de Santa Isabel, leitor de Theologia, Custodio actual, \& Procurador da mesma Provincia, Visitador, \& Presidente do Capitulo, que se celebrou na Provincia de Sãto Antonio dos Capuchos de Portugal. Lisboa: Na Officina de Manoel \& Joseph Lopes Ferreyra, MDCCIX [1709]. Disponível em: <http://purl.pt/>. Acesso em: 02 jan. 2012. 
FANTUZZI, Giovanni. Notizie degli scrittori bolognesi. Bolonha: Nella Stamperia de S. Tommaso D'Aquino, MDCCLXXXIX [1789]. Disponível em: 〈http://books.google.com.br/〉. Acesso em: 01 jun. 2018.

JABOATAM, Fr. Antonio de Santa Maria (OFM). Orbe serafico novo brasilico, descoberto, estabelecido, e cultivado etc., parte primeira, etc. Lisboa: Na Officina de Antonio Vicente da Silva, MDCCLXI [1761]. Disponível em: <http://www.bibliotecadigital.unicamp.br/>. Acesso em: 20 fev. 2016.

JABOATAM, Fr. Antonio de Santa Maria (OFM). Novo Orbe Serafico Brasilico ou Chronica dos Frades Menores da Província do Brasil -2 vols. Rio de Janeiro: Typographia Brasiliense de Maximiano Gomes Ribeiro, 1858. Disponível em: <http://books.google.com.br/>. Acesso em: 02 jul. 2010.

LIVRO dos Inventarios dos Conventos do Norte [em 5 de julho de 1852], Fr. Antônio da Rainha dos Anjos Machado (OFM), manuscrito, 104 fólios. Arquivo Provincial Franciscano do Recife - APFR, Pernambuco, Brasil.

RICHEOME, Louis (SJ). Tableaux sacrez des figures mystiques du très auguste sacrifice et sacrement de l'Eucharistie. À Paris: chez Laurens Sonnius, 1601. Disponível em: <http://books.google.com.br/>. Acesso em: 21 abr. 2018.

VAN VEEN, Otto. Theatro Moral de la Vida Humana en cien emblemas con el Enchiridion de Epicteto, y la Tabla de Cebes, philosofo platonico. Antuérpia: Pela viúva de Henrico Verdussen, Año MDCCXXXIII [1733]. Disponível em: 〈http://www.archive.org/>. Acesso em: 17 jul. 2016.

VOCABULARIO Portuguez, e Latino, Aulico, Anatomico, Architectonico, Bellico, Botanico, Brasilico, Comico, Critico, Chimico, Dogmatico, Dialectico, Dendrologico, Ecclesiastico, Etymologico, Economico, Florifero, Forense, Fructifero, Geographico, Geometrico, Gnomonico, Hydrographico, Homonymico, Hierologico, Ichtuologico, Indico, Ifagogico, Laconico, Liturgico, Lithologico, Medico, Musico, Meteorologico, Nautico, Numerico, Neoterico, Ortographico, Optico, Ornithologico, Poetico, Philologico, Pharmaceutico, Quidditativo, Qualitativo, Quantitativo, Rethorico, Rustico, Romano; Symbolico, Synonimico, Syllabico, Theologico, Terapeutico, Technologico, Uranologico, Xenophonico, Zoologico, Autorizado com exemplos dos melhores escritores portuguezes, e latinos, e offerecido a El Rey de Portvgal, D. Joaõ V, pelo Padre D. Raphael Bluteau clerigo regular, Doutor na Sagrada Theologia, Prêgador da Raynha de Inglaterra, Henriqueta Maria de França, \& Calificador no Sagrado Tribunal da Inquisição de Lisboa. Tomo 3. D=E. Coimbra: No Collegio das Artes da Companhia de Jesu, Anno de 1712. Disponível em: <https://www.bbm.usp.br/>. Acesso em: 20 fev. 2016.

VOCABULARIO Portuguez, e Latino, Aulico, Anatomico, Architectonico, Bellico, Botanico, Brasilico,Comico, Critico, Chimico, Dogmatico, Dialectico, Dendrologico, Ecclesiastico, Etymologico, Economico, Florifero, Forenfse, Fructifero, Geographico, Geometrico, Gnomonico, Hydrographico, Homonymico, Hierologico, Ichtyologico, Indico, Isagogico, Laconico, Liturgico, Lithologico, Medico, Musico, Meteorologico, Nautico, Numerico, Neoterico, Ortographico, Optico, Ornithologico, Poetico, Philologico, Pharmaceutico, Quidditadvo, Qualitativo, Quantitativo, Rhetorico, Rustico, Romano, Symbolico, Synonimico, 
Syllabico, Theologico, Terapeutico, Technologico, Uranologico, Xenophonico, Zoologico, Authorizado com exemplos, dos Melhores Escritores Portuguezes, \& Latinos, E Offerecido A El Rey de Portugal Dom Joam V. Pelo Padre D. Raphael Bluteau Clerigo Regular, Doutor na Sagrada Theologia, Prègador da Rainha de Inglaterra, Henriqueta Maria de França, \& Qualificador no Sagrado Tribunal da Inquisiçaõ de Lisboa. Tomo V. K=N. Lisboa: Na Officina de Pascoal da Sylva, MDCCXVI [1716]. Disponível em: 〈https://www.bbm.usp.br/>. Acesso em: 20 fev. 2016.

WILLEKE, Fr. Venancio (OFM) - Prefácio e notas. Livro dos Guardiães do Convento de São Francisco da Bahia (1587-1862). Rio de Janeiro: MEC; IPHAN, 1978.

\section{Referências}

ALMEIDA, Marcos Antonio de. "L'Orbe Serafico, Novo Brasilico": Jaboatão et les franciscains à Pernambouc au XVIII e siécle. 2 vols. Tese (Doutorado em História Moderna). École des Hautes Études en Sciences Sociales. Paris, 2012.

AMORIM, Maria Adelina. "A formação dos franciscanos no Brasil-Colónia à luz dos textos legais”. Lusitania Sacra, 2a série, n. 11, 1999, p. 361-377.

BAZIN, Germain. A arquitetura religiosa barroca no Brasil. 2 vols. Tradução de Glória Lúcia Nunes. Rio de Janeiro: Record, 1983 [1956].

BÉRIOU, Nicole; MORARD, Martin \& DALLA GUARDA, Donatella Nebbiai (orgs.). Entre stabilité et itinérance: Livres et culture des ordres mendicants, XIIIe-XVe siècle. Turnhout: Brepols, 2014. https://doi.org/10.1484/M.BIB-EB.6.09070802050003050500010900

CORNELLES, Víctor Mínguez. "Philosophia Vitae Magistra: Horacio en emblemas flamencos". In: VÁZQUEZ, José Manuel B. López \& MONTERO, Juan M. Monterroso (orgs.). Virtus Inconcussa: estudios en torno al 'Theatro Moral de la Vida Humana' de Otto Vaenius. La Coruña: Deputación Provincial da Coruña, 2013, p. 23-37.

COSTA, Francisco Augusto Pereira da Costa. Anais Pernambucanos - Vol. IX: 1824-1833. Recife: Arquivo Público Estadual, 1965.

FRAGOSO, Fr. Hugo (OFM). "Biblioteca do Convento de São Francisco". In: LOMBARDI, José Claudinei; SAVIANI, Dermeval \& NASCIMENTO, Maria Isabel Moura (orgs.). Navegando na História da Educação Brasileira - HISTEDBR. Campinas: HISTEDBR; FEUNICAMP, 2006, p. 1-7. CD-ROM.

FRAGOSO, Fr. Hugo (OFM). “Azulejos do Convento de São Francisco”. In: FLEXOR, Maria Helena Ochi \& (orgs.). Igreja e Convento de São Francisco da Bahia. Rio de Janeiro: Versal, 2009, p. 317-371. 
GOMES, Luís. "Emblema" [verbete]. In: CEIA, Carlos (org.). E-Dicionário de Termos Literários. Lisboa: $\quad$ FCSH-UNL, 2009. Disponível em: <http://edtl.fcsh.unl.pt/encyclopedia/emblema/>. Acesso em: 02 jun. 2018.

KLUCKERT, Ehrenfried. “Emblemática”. In: TOMAN, Rolf (org.). O Barroco: arquitectura, escultura, pintura. Tradução de Maria da Luz Cidreiro Lopes e equipe. Königswinter: Könemann; Tandem Verlag, 2004, p. 428-429.

KRIEGER, Michael T. "The Seminary Libraries of the Franciscan Province of St. John the Baptist". Libraries \& Culture, vol. 30, n. 3, 1995, p. 284-308. Disponível em: <http://www.jstor.org/>. Acesso em: 17 abr. 2018.

JONES, W. R. "Franciscan education and monastic libraries: some documents". Traditio, vol. 30, 1974, p. 435-445. Disponível em: <http://www.jstor.org/>. Acesso em: 17 abr. 2018. https://doi.org/10.1017/S0362152900006607

MECO, José. “A expansão da Azulejaria portuguesa”. Oceanos, Lisboa, Dossiê “Azulejos: Portugal e Brasil”, n. 36/37, out. 1998 /mar. 1999, p. 8-17.

MIRANDA, Maria do Carmo Tavares de. Os franciscanos e a formação do Brasil. Recife: Edições da Universidade Federal de Pernambuco, 1969.

MOORMAN, John. "The old learning and the new". In: . A history of the Franciscan Order from its origins to the year 1517. Oxford: Claredon Press, 1968, p. 533-547.

OLIVEIRA, Carla Mary S. "Livros e leitores em Pernambuco entre o Setecentos e o Oitocentos: a instrução e as livrarias franciscanas". Portuguese Studies Review, Peterborough, Trent University, v.24, n.2, 2016, p.37-62. Disponível em: https://ufpb.academia.edu/CarlaMaryOliveira.

PALUMBO, Genoveffa. "Mondo reale e mondo ideale nel frontespizio del Mondo Simbolico di Filippo Picinelli (1653-54 e 1669)". In: ZAFRA, Rafael \& AZANZA, José Javier (orgs.). Emblemática trascendente: hermenéutica de la imagen, iconología del texto. Pamplona: Sociedad Española de Emblemática; Universidad de Navarra, 2011, p. 619-638.

PRAZ, Mario. Imágenes del Barroco: estudios de Emblemática. Tradução de José María Parreño. 2. ed. Madri: Ediciones Siruela, 2005 [1934].

ROEST, Bert. A history of Franciscan education (c. 1210-1517). Leiden \& Boston: Brill, 2000.

ROEST, Bert. Franciscan literature of religious instruction before the Council of Trent. Leiden \& Boston: Brill, 2004.

ROEST, Bert. Franciscan learning, preaching and mission - c. 1220-1650: "Cum scientia sit donum Dei, armature ad defendendam sanctam fidem catholicam...”. Leiden \& Boston: Brill, 2015.

ŞENOCAK, Neslihan. "Book acquisition in the medieval Franciscan Order". The Journal of Religious History, vol. 27, n. 1, fev. 2003, p. 14-28. https://doi.org/10.1111/1467-9809.00162 
ŞENOCAK, Neslihan. "Circulation of books in the medieval Franciscan Order: attitude, methods, and critics". The Journal of Religious History, vol. 28, n. 2, jun. 2004, p. 146-161. https://doi.org/10.1111/j.1467-9809.2004.00210.x

ŞENOCAK, Neslihan. The poor and the perfect: the rise of learning in the Franciscan order, 1209-1310. Ithaca \& Londres: Cornell University Press, 2012a.

ŞENOCAK, Neslihan. "The Franciscan studium generale: a new interpretation". In: EMERY JR., Kent; COURTENAY, William J. \& METZGER, Stephen M. (orgs.). Philosophy and Theology in the 'Studia' of the Religious Orders and at Papal and Royal Courts $-\mathrm{XV}^{\text {th }}$ Annual Colloquium of the Société Internationale pour l'Étude de la Philosophie Médiévale - Acts. Turnhout: Brepols, 2012b, p. 221-236.

VERA, René Hernández. "A space in the cupboard: the organization of the book collection in the Franciscan Convent of Sant'Antonio in Padua during the Fifteenth century". Bulletin of International Medieval Research, n. 19, 2013, p. 101-121.

WILLEKE, Fr. Venâncio (OFM). "Convento de Santo Antônio de Ipojuca". Revista do Patrimônio Histórico e Artístico Nacional, Rio de Janeiro, SPHAN, n. 13, 1956, p. 255-358. 